\title{
Description and basic evaluation of Beijing Normal University Earth System Model (BNU-ESM) version 1
}

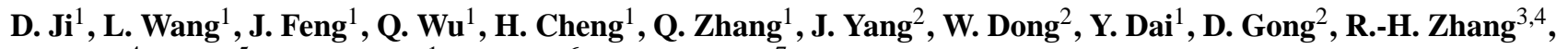 \\ X. Wang ${ }^{4}$, J. Liu ${ }^{5}$, J. C. Moore ${ }^{1}$, D. Chen ${ }^{6}$, and M. Zhou ${ }^{7}$ \\ ${ }^{1}$ College of Global Change and Earth System Science, Beijing Normal University, Beijing 100875, China \\ ${ }^{2}$ State Key Laboratory of Earth Surface Processes and Resource Ecology, Beijing Normal University, Beijing 100875, China \\ ${ }^{3}$ Key Laboratory of Ocean Circulation and Waves, Institute of Oceanology, Chinese Academy of Sciences, \\ Qingdao 266071, China \\ ${ }^{4}$ Earth System Science Interdisciplinary Center (ESSIC), University of Maryland, College Park, MD 20742, USA \\ ${ }^{5}$ Department of Atmospheric and Environmental Sciences, University at Albany, State University of New York, \\ Albany, NY, USA \\ ${ }^{6}$ National Parallel Computer Engineering Technology Research Center, Beijing 100190, China \\ ${ }^{7}$ Jiangnan Institute of Computing Technology, Wuxi 214083, China
}

Correspondence to: L. Wang (wangln@bnu.edu.cn) and D.Ji (duoyingji@bnu.edu.cn)

Received: 31 January 2014 - Published in Geosci. Model Dev. Discuss.: 4 March 2014

Revised: 6 July 2014 - Accepted: 10 August 2014 - Published: 12 September 2014

\begin{abstract}
An earth system model has been developed at Beijing Normal University (Beijing Normal University Earth System Model, BNU-ESM); the model is based on several widely evaluated climate model components and is used to study mechanisms of ocean-atmosphere interactions, natural climate variability and carbon-climate feedbacks at interannual to interdecadal time scales. In this paper, the model structure and individual components are described briefly. Further, results for the CMIP5 (Coupled Model Intercomparison Project phase 5) pre-industrial control and historical simulations are presented to demonstrate the model's performance in terms of the mean model state and the internal variability. It is illustrated that BNU-ESM can simulate many observed features of the earth climate system, such as the climatological annual cycle of surface-air temperature and precipitation, annual cycle of tropical Pacific sea surface temperature (SST), the overall patterns and positions of cells in global ocean meridional overturning circulation. For example, the El Niño-Southern Oscillation (ENSO) simulated in BNU-ESM exhibits an irregular oscillation between 2 and 5 years with the seasonal phase locking feature of ENSO. Important biases with regard to observations are presented and discussed, including warm SST discrepancies in the major upwelling regions, an equatorward drift of midlatitude
\end{abstract}

westerly wind bands, and tropical precipitation bias over the ocean that is related to the double Intertropical Convergence Zone (ITCZ).

\section{Introduction}

Climate models are the essential tools to investigate the response of the climate system to various forcings, to make climate predictions on seasonal to decadal time scales and to make projections of future climate (Flato et al., 2013). At Beijing Normal University, with collaboration from several model development centers in China, the BNU-ESM (Beijing Normal University Earth System Model) comprising atmospheric, land, oceanic, and sea ice components along with carbon cycles has recently been developed. The development of BNU-ESM was prompted by foundation of a new multidisciplinary research center committed to study global change and earth system science in Beijing Normal University. The BNU-ESM takes advantage of contemporary model achievements from several well-known modeling centers, and its components were chosen based on the specific expertise and experience available to the research center, and 
furthermore with an eye to how the research strengths of the center can improve and develop it.

The coupling framework of BNU-ESM is based on an interim version of the Community Climate System Model version 4 (CCSM4) (Gent et al., 2011; Vertenstein et al., 2010) developed at the National Center for Atmospheric Research (NCAR) on behalf of the Community Climate System Model/Community Earth System Model (CCSM/CESM) project of the University Corporation for Atmospheric Research (UCAR). Notably, BNU-ESM differs from CCSM4 in the following major aspects: (i) BNU-ESM utilizes the Modular Ocean Model version 4p1 (MOM4p1) (Griffies, 2010) developed at Geophysical Fluid Dynamics Laboratory (GFDL). (ii) The land surface component of BNUESM is the Common Land Model (CoLM) (Dai et al., 2003, 2004; Ji and Dai, 2010) initially developed by a community and further improved at Beijing Normal University. (iii) The CoLM has a global dynamic vegetation sub-model and terrestrial carbon and nitrogen cycles based on the LundPotsdam-Jena model (LPJ) (Sitch et al., 2003) and the LundPotsdam-Jena Dynamic Nitrogen scheme (LPJ-DyN) (Xu and Prentice, 2008). The LPJ-DyN based terrestrial carbon and nitrogen interaction schemes are very different from the biogeochemistry Carbon-Nitrogen scheme used in CLM4 or CCSM4 (Thornton and Rosenbloom, 2005; Oleson et al., 2010; Lawrence et al., 2011). (iv) The atmospheric component is an interim version of the Community Atmospheric Model version 4 (CAM4) (Neale et al., 2010, 2013) modified with a revised Zhang-McFarlane deep convection scheme (Zhang and McFarlane, 1995; Zhang, 2002; Zhang and Mu, 2005a). (v) The sea ice component is the Community Ice CodE (CICE) version 4.1 (Hunke and Lipscomb, 2010) developed at Los Alamos National Lab (LANL), while the sea ice component of CCSM4 is based on Version 4 of CICE. These variations illustrate how the BNU-ESM adds to the much-desired climate model diversity, and thus to the hierarchy of models participating in the Climate Model Intercomparison Projects phase 5 (CMIP5) (Taylor et al., 2012).

As a member of CMIP5, BNU-ESM has completed all core simulations within the suite of CMIP5 long-term experiments and some of related tier-1 integrations intended to examine specific aspects of climate model forcing, response, and processes. The long-term experiments performed with BNU-ESM include a group forced by observed atmospheric composition changes or specified concentrations (e.g., $p i$ Control, historical, rcp45 and rcp85 labeled by CMIP5), and a group driven by time-evolving emissions of constituents from which concentrations can be computed interactively (e.g., esmControl, esmHistorical and esmrcp85 labeled by CMIP5). At the same time, BNU-ESM joined the Geoengineearing Model Intercomparison Project (GeoMIP) and completed its first suite of experiments (G1-G4; Kravitz et al., 2011) concentrating on solar radiation management (SRM) schemes (e.g., Moore et al., 2014). Data for all CMIP5 and GeoMIP simulations completed by BNU-ESM have been published via an Earth System Grid Data Node located at Beijing Normal University (BNU) and can be accessed at http://esg.bnu.edu.cn, as a part of internationally federated, distributed data archival and retrieval system, referred to as the Earth System Grid Federation (ESGF).

Many studies have utilized CMIP5 results from BNUESM, and the model has received comprehensive evaluations. For example, Wu et al. (2013) evaluated the precipitation-surface temperature $(P-T)$ relationship of BNU-ESM among 17 models in CMIP5 and found BNUESM has better ability in simulating $P-T$ pattern correlation than other models, especially over ocean and tropics. Bellenger et al. (2013) used the metrics developed within the Climate Variability and Predictability (CLIVAR) Pacific Panel and additional metrics to evaluate the basic El NiñoSouthern Oscillation (ENSO) properties and associated feedbacks of BNU-ESM and other CMIP5 models. BNU-ESM performs well on simulating precipitation anomalies over the Niño-4 region; the ratio between the ENSO spectral energy in the 1-3 year band and in 3-8 year band is well consistent with observational result, but the model has stronger sea surface temperature (SST) anomalies than observational estimates over Niño-3 and Niño-4 regions. Fettweis et al. (2013) reported BNU-ESM can simulate the 1961-1990 variability of the June-August (JJA) North Atlantic Oscillation (NAO) well and the sharp decrease of the NAO index over the last 10 years as observed, and the model projects similar negative NAO values into the future under RCP 8.5 scenario. Gillett and Fyfe (2013) reported no significant Northern Annular Mode (NAM) decrease in any season between 1861 and 2099 in historical and rcp45 simulations of BNU-ESM as with the other 36 models from CMIP5. Bracegirdle et al. (2013) assessed the model's simulation of near-surface westerly winds over the Southern Ocean and found an equatorward bias in the present-day zonal mean surface jet position in common with many of the CMIP5 models. Among other studies, Chen et al. (2013) evaluated the cloud and water vapor feedbacks to El Niño warming in BNU-ESM. Vial et al. (2013) diagnosed the climate sensitivity, radiative forcing and climate feedback of BNU-ESM. Roehrig et al. (2013) assessed the performance of BNU-ESM on simulating the West African Monsoon. Sillmann et al. (2013) evaluated the model performance on simulating climate extreme indices defined by the Expert Team on Climate Change Detection and Indices (ETCCDI). Wei et al. (2012) utilized BNU-ESM in assessment of developed and developing world responsibilities for historical climate change and $\mathrm{CO}_{2}$ mitigation.

Although the simulation results from BNU-ESM are widely used in many climate studies, a general description of the model itself and its control climate is still not available. Documenting the main features of the model structure and its underlying parameterization schemes will help the climate community to further understand the results from BNUESM. 
This paper provides a general description and basic evaluation of the historical climate simulated by BNU-ESM. Particular focus is put on the model structure, the simulated climatology, internal climate variability and terrestrial carbon cycle deduced from the piControl and historical simulations submitted for CMIP5. The climate response and scenario projections in BNU-ESM will be covered elsewhere. The paper is organized as follows. In Sect. 2, a general overview of BNU-ESM is provided, elaborating on similarities and differences between the original and revised model components in BNU-ESM. In Sect. 3, the design of the piControl and historical model experiments is briefly presented, as well as the spin-up strategy. In Sect. 4, the general model performance is evaluated by using the Taylor diagram (Taylor, 2001). The following two sections focus on the model performance on simulating physical climatology and climate variability. Several key modes of internal variability on different timescales ranging from interseasonal to interdecadal are evaluated. The terrestrial carbon cycle is evaluated in Sect. 7, and particular focus is put on terrestrial primary productions and soil organic carbon stocks. Finally, the paper is summarized and discussed in Sect. 8.

\section{Model description}

\subsection{Atmospheric model}

The atmospheric component in BNU-ESM is based on Community Atmospheric Model version 3.5 (CAM3.5), which is an interim version of the Community Atmospheric Model version 4 (CAM4) (Neale et al., 2010, 2013). Here, the main difference of the atmospheric component in BNU-ESM relative to the original CAM3.5 model is the process of deep convection. The BNU-ESM uses a modified Zhang-McFarlane scheme in which a revised closure scheme couples convection to the large-scale forcing in the free troposphere instead of to the convective available potential energy in the atmosphere (Zhang, 2002; Zhang and Mu, 2005a). On the other hand CAM3.5 adopts a Zhang-McFarlane scheme (Zhang and McFarlane, 1995) modified with the addition of convective momentum transports (Richter and Rasch, 2008), and a modified dilute plume calculation (Neale et al., 2008) following Raymond and Blyth (1986, 1992). BNU-ESM uses the Eulerian dynamical core in CAM3.5 for transport calculations with a T42 horizontal spectral resolution (approximately $2.81^{\circ} \times 2.81^{\circ}$ transform grid), with 26 levels in the vertical of a hybrid sigma-pressure coordinates and model top at $2.917 \mathrm{hPa}$. Atmospheric chemical processes utilize the tropospheric MOZART (TROP-MOZART) framework in CAM3.5 (Lamarque et al., 2010), which has prognostic greenhouse gases and prescribed aerosols. Note that the aerosols do not directly interact with the cloud scheme so that any indirect effects are omitted in CAM3.5, as well as in BNU-ESM.

\subsection{Ocean model}

The ocean component in BNU-ESM is based on the GFDL Modular Ocean Model version 4p1 (MOM4p1) released in 2009 (Griffies, 2010). The oceanic physics is unchanged from the standard MOM4p1 model, and the main modifications are in the general geometry and geography of the ocean component. MOM4p1 uses a tripolar grid to avoid the polar singularity over the Arctic, in which the two northern poles of the curvilinear grid are shifted to land areas over North America and Eurasia (Murray, 1996). In BNU-ESM, MOM4p1 uses a nominal latitude-longitude resolution of $1^{\circ}$ (down to $1 / 3^{\circ}$ within $10^{\circ}$ of the equatorial tropics) with 360 longitudinal grids and 200 latitudinal grids, and there are 50 vertical levels with the uppermost 23 layers each being $10.143 \mathrm{~m}$ thick. The mixed layer is represented by the $K$ profile parameterization (KPP) of vertical mixing (Large et al., 1994). The idealized ocean biogeochemistry (iBGC) module is used in BNU-ESM, which carries a single prognostic macronutrient tracer (phosphate, $\mathrm{PO}_{4}$ ), and simulates two main representative biogeochemical processes, i.e., the net biological uptake in the euphotic zone due to phytoplankton activity as a function of temperature, light and phosphate availability, and regeneration of phosphate as an exponential function below the euphotic zone.

\subsection{Sea ice model}

The BNU-ESM sea ice component is the Los Alamos sea ice model (CICE) version 4.1 (Hunke and Lipscomb, 2010). The CICE was originally developed to be compatible with the Parallel Ocean Program (POP), but has been greatly enhanced in its technical and physical compatibility with different models in recent years. In particular, supporting tripolar grids makes it easier to couple with MOM4p1 code. In BNUESM, CICE uses its default shortwave scheme, in which the penetrating solar radiation is equal to zero for snow-covered ice, that is, most of the incoming sunlight is absorbed near the top surface. The visible and near infrared albedos for thick ice and cold snow are set to 0.77, 0.35, 0.96 and 0.69, respectively, slightly smaller than the standard CICE configuration, as they are used as tuning parameters during model control integration. The surface temperature of ice or snow is calculated in CICE without exploiting its "zero-layer" thermodynamic scheme, and the "bubbly brine" model based parameterization of ice thermal conductivity is used.

\subsection{Land model}

The land component in BNU-ESM is the Common Land Model (CoLM), which was initially developed by incorporating the best features of three earlier land models: the biosphere-atmosphere transfer scheme (BATS) (Dickinson et al., 1993), the 1994 version of the Chinese Academy of Sciences Institute of Atmospheric Physics LSM (IAP94) 
(Dai and Zeng, 1997) and the NCAR Land Surface Model (LSM) (Bonan, 1996, 1998). The CoLM was documented by Dai et al. (2001) and introduced to the modeling community in Dai et al. (2003). The initial version of CoLM was adopted as the Community Land Model (CLM) for use with the Community Climate System Model (CCSM). The land model was then developed separately at NCAR and BNU. Currently, the CoLM is radically different from its initial version and the CLM (Dai et al., 2004; Bonan et al., 2011); including the following: (i) improved two stream approximation model of radiation transfer of the canopy, with attention to singularities in its solution and with separate integrations of radiation absorption by sunlit and shaded fractions of canopy. (ii) A photosynthesis-stomatal conductance model for sunlit and shaded leaves separately, and for the simultaneous transfers of $\mathrm{CO}_{2}$ and water vapor into and out of the leaf. (iii) Lund-Potsdam-Jena (LPJ) model (Sitch et al., 2003) based dynamical global vegetation model and terrestrial carbon cycle, and LPJ-DyN (Xu and Prentice, 2008) based scheme on carbon-nitrogen cycle interactions. Note that in all BNU-ESM's CMIP5 and GeoMIP simulations, carbon-nitrogen cycle interactions are turned off as the nitrogen cycle has not yet been fully evaluated.

\subsection{Component coupling}

The coupling framework of BNU-ESM is largely based on the coupler in NCAR CCSM3.5 (an interim version of NCAR CCSM4), with changes on grid mapping interpolation to allow for the identical tripolar grids used in both ocean and sea ice components. The time evolution of the whole model and communication between various component models are all synchronized and controlled by the coupler in the BNU-ESM. Since MOM4p1 and CICE4.1 are both Arakawa B-grid models, the coupling between them is efficient, and the exchanged fields need no transformation or additional treatment (e.g., vector rotation, grid remapping, grid-point shifting, etc.). The different model components are run simultaneously from their initial conditions. The atmospheric component uses a $1 \mathrm{~h}$ time step for atmospheric radiation and 20 min time step for other atmospheric physics. The ocean, sea ice and land components have a $2 \mathrm{~h}, 1 \mathrm{~h}$ and $30 \mathrm{~min}$ time step, respectively, while direct coupling occurs hourly among atmospheric, sea ice and land components, and daily with the ocean component without any flux adjustment.

All biogeochemical components are driven by the physical climate with the biogeochemical feedback loops combined. The terrestrial carbon cycle module determines the exchange of $\mathrm{CO}_{2}$ between the land and the atmosphere. It is coupled to the physical climate through the vegetation distribution and leaf area index, which affects the surface albedo, the evapotranspiration flux and so on. As with the terrestrial carbon cycle module, the ocean biogeochemistry module calculates the ocean-atmosphere exchange of $\mathrm{CO}_{2}$, and both are

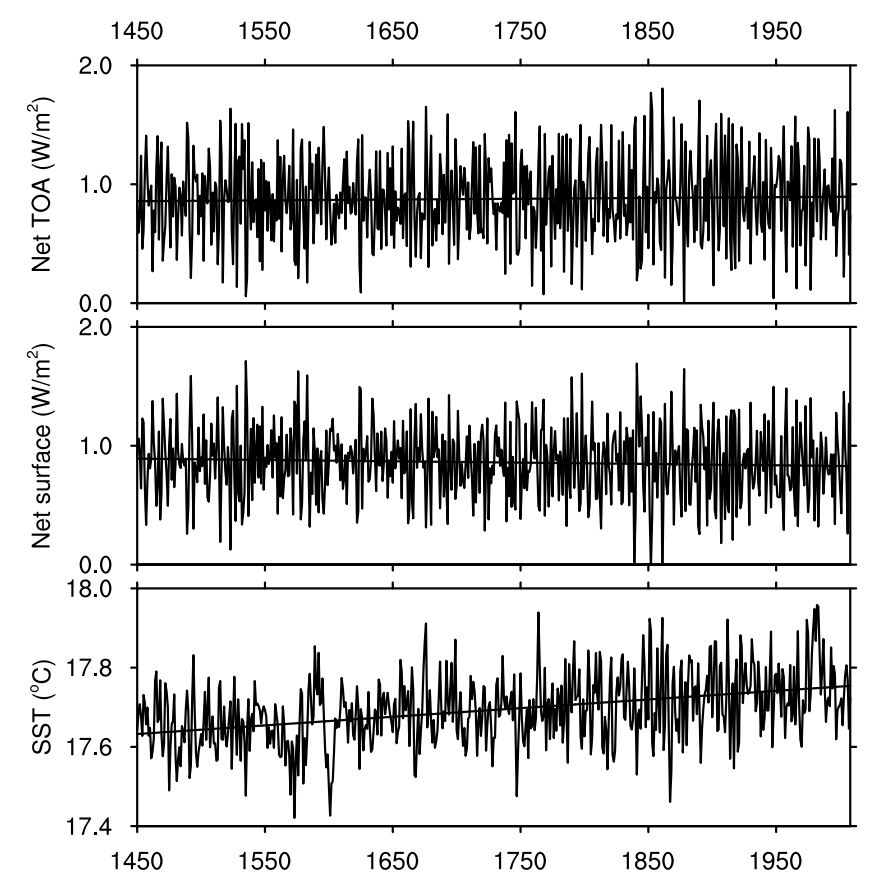

Figure 1. The global mean TOA and surface net radiation flux, global mean SST over the piControl simulation period. The black lines are linear regressions.

coupled with the TROP-MOZART framework in the atmospheric component to form a closed carbon cycle.

\section{Experiments}

Following CMIP5 specifications (Taylor et al., 2009), BNUESM has performed all CMIP5 long-term core experiments and part of the tier- 1 experiments. The CMIP5 specification requires each model to reach its equilibrium states before kicking off formal simulations, especially for long-term control experiments. BNU-ESM adopted a two-step spin-up strategy to achieve model equilibrium. Firstly, the land component including vegetation dynamics and terrestrial carbon cycle, and the ocean component including biogeochemical module were separately spun-up to yield an initial estimate of equilibrium states. In these off-line integrations of the first step spin-up, surface physical quantities such as winds, temperature, precipitation, moisture, and radiation flux are taken as the climatology of a pre-industrial run of the fully coupled BNU-ESM with carbon cycles turned off. Then, the resultant equilibrated physical and carbon cycle states were fed into the coupled model as initial conditions to do on-line spin-up to achieve final equilibrium states. During the second stage, the coupled model was forced with constant external conditions as specified for CMIP5 pre-industrial control simulation as stated below. 
Table 1. Observationally based reference data sets.

\begin{tabular}{|c|c|c|c|}
\hline Variable ID & Description & Reference1/Reference2 & Domain \\
\hline ta & temperature $\left[{ }^{\circ} \mathrm{C}\right]$ & ERA-Interim ${ }^{\mathrm{a}} / \mathrm{JRA}-55^{\mathrm{b}}$ & $200,850 \mathrm{hPa}$ \\
\hline ua & zonal wind $\left[\mathrm{m} \mathrm{s}^{-1}\right]$ & ERA-Interim ${ }^{\mathrm{a}} / \mathrm{JRA}-55^{\mathrm{b}}$ & $200,850 \mathrm{hPa}$ \\
\hline va & meridional wind $\left[\mathrm{m} \mathrm{s}^{-1}\right]$ & ERA-Interim ${ }^{\mathrm{a}} / \mathrm{JRA}-55^{\mathrm{b}}$ & $200,850 \mathrm{hPa}$ \\
\hline $\mathrm{zg}$ & geopotential height $[\mathrm{m}]$ & ERA-Interim ${ }^{\mathrm{a}} / \mathrm{JRA}-55^{\mathrm{b}}$ & $500 \mathrm{hPa}$ \\
\hline hus & specific humidity $\left[\mathrm{kg} \mathrm{kg}^{-1}\right]$ & ERA-Interim $^{\mathrm{a}} / \mathrm{MERRA}^{\mathrm{c}}$ & $400,850 \mathrm{hPa}$ \\
\hline rlut & TOA outgoing long-wave radiation $\left[\mathrm{W} \mathrm{m}^{-2}\right]$ & ERBE $^{\mathrm{d}} / \mathrm{CERES}^{\prime} \mathrm{EBAF}^{\mathrm{e}}$ & \\
\hline rsnt & TOA net shortwave radiation $\left[\mathrm{W} \mathrm{m}^{-2}\right]$ & ERBE $^{\mathrm{d}} /$ CERES-EBAF $^{\mathrm{e}}$ & \\
\hline rlwcrf & long-wave cloud radiative forcing $\left[\mathrm{W} \mathrm{m}^{-2}\right]$ & $\mathrm{ERBE}^{\mathrm{d}} / \mathrm{CERES} \mathrm{EBAF}^{\mathrm{e}}$ & equatorward of $60^{\circ}$ \\
\hline rswcrf & shortwave cloud radiative forcing $\left[\mathrm{W} \mathrm{m}^{-2}\right]$ & $\mathrm{ERBE}^{\mathrm{d}} / \mathrm{CERES}_{\mathrm{EBAF}}^{\mathrm{e}}$ & equatorward of $60^{\circ}$ \\
\hline $\mathrm{pr}$ & total precipitation $\left[\mathrm{mm} \mathrm{day}^{-1}\right]$ & $\mathrm{GPCP}^{\mathrm{f}} / \mathrm{CMAPg}$ & \\
\hline clt & total cloud cover $[\%]$ & ISCCP-D $^{\mathrm{h}} /$ CLOUDSAT $^{\mathrm{i}}$ & \\
\hline prw & precipitable water $\left[\mathrm{g} \mathrm{kg}^{-1}\right]$ & $\mathrm{RSS}(\mathrm{v} 7)^{\mathrm{j}} / \mathrm{NVAP}^{\mathrm{k}}$ & \\
\hline psl & sea level pressure $[\mathrm{Pa}]$ & ERA-Interim ${ }^{\mathrm{a}} / \mathrm{JRA}-55^{\mathrm{b}}$ & ocean only \\
\hline uas & surface $(10 \mathrm{~m})$ zonal wind speed $\left[\mathrm{m} \mathrm{s}^{-1}\right]$ & ERA-Interim ${ }^{\mathrm{a}} / \mathrm{JRA}-55^{\mathrm{b}}$ & ocean only \\
\hline vas & surface $(10 \mathrm{~m})$ meridional wind speed $\left[\mathrm{m} \mathrm{s}^{-1}\right]$ & ERA-Interim ${ }^{\mathrm{a}} / \mathrm{JRA}-55^{\mathrm{b}}$ & ocean only \\
\hline tos & sea surface temperature $\left[{ }^{\circ} \mathrm{C}\right]$ & $\operatorname{HadISST}^{1} /$ OISST(v2) ${ }^{\mathrm{m}}$ & ocean only, equatorward of $50^{\circ}$ \\
\hline tauu & ocean surface zonal wind stress $[\mathrm{Pa}]$ & ERA-Interim ${ }^{\mathrm{a}} / \mathrm{NOCS}^{\mathrm{n}}$ & ocean only \\
\hline tauv & ocean surface meridional wind stress $[\mathrm{Pa}]$ & ERA-Interim ${ }^{\mathrm{a}} / \mathrm{NOCS}^{\mathrm{n}}$ & ocean only \\
\hline hfls(ocn) & ocean surface latent heat flux [W m $\left.{ }^{-2}\right]$ & ERA-Interim $^{\mathrm{a}} / \mathrm{NOCS}^{\mathrm{n}}$ & ocean only \\
\hline hfss(ocn) & ocean surface sensible heat flux $\left[\mathrm{W} \mathrm{m}^{-2}\right]$ & ERA-Interim ${ }^{\mathrm{a}} / \mathrm{NOCS}^{\mathrm{n}}$ & ocean only \\
\hline hfls(lnd) & land surface latent heat flux $\left[\mathrm{W} \mathrm{m}^{-2}\right]$ & ERA-Interim $^{\mathrm{a}} /$ FLUXNET-MTE $^{\mathrm{O}}$ & land only \\
\hline hfss(lnd) & land surface sensible heat flux [W m $\left.{ }^{-2}\right]$ & ERA-Interim $^{\mathrm{a}} /$ FLUXNET-MTE $^{\mathrm{o}}$ & land only \\
\hline gpp & gross primary productivity $\left[\mathrm{kg} \mathrm{m}^{-2} \mathrm{~s}^{-1}\right]$ & FLUXNET-MTE ${ }^{\circ}$ & land only \\
\hline fgco 2 & surface $\mathrm{CO}_{2}$ flux $\left[\mathrm{kg} \mathrm{m}^{-2} \mathrm{~s}^{-1}\right]$ & $\mathrm{LDEO}^{\mathrm{p}}$ & ocean only \\
\hline
\end{tabular}

${ }^{a}$ ERA-Interim (Dee et al., 2011); ${ }^{\text {b }}$ JRA-55 (Ebita et al., 2011); ${ }^{\mathrm{c}}$ MERRA (Rienecker et al., 2011); ${ }^{\mathrm{d}}$ ERBE (Barkstrom, 1984); ${ }^{\mathrm{e}}$ CERES-EBAF (Loeb et al., 2009); ${ }^{\mathrm{f}}$ GPCP (Adler et al., 2003); ${ }^{\mathrm{g}}$ CMAP (Xie and Arkin, 1997); ${ }^{\mathrm{h}}$ ISCCP-D2 (Rossow and Schiffer, 1999; Rossow and Dueñas, 2004); ${ }^{\mathrm{i}}$ CLOUDSAT (L'Ecuyer et al., 2008); ${ }^{\mathrm{j}}$ RSS (Wentz, 2000, 2013); ${ }^{\mathrm{k}}$ NVAP (Simpson et al., 2001); ${ }^{1}$ HadISST (Rayner et al., 2003); ${ }^{\mathrm{m}}$ OISST (Reynolds et al., 2002); ${ }^{\mathrm{n}}$ NOCS (Josey et al., 1999); ${ }^{\mathrm{o}}$ FLUXNET-MTE (Jung et al., 2011); P LDEO (Takahashi et al., 2009).

In this paper, we focus on the 559 year (from model year 1450 to 2008) pre-industrial control simulation (piControl) and 156 year historical simulation representing the historical period from year 1850 to 2005 . The piControl simulation is integrated with constant external forcing prescribed at 1850 conditions (the solar constant is $1365.885 \mathrm{~W} \mathrm{~m}^{-2}$, the concentrations of $\mathrm{CO}_{2}, \mathrm{CH}_{4}, \mathrm{~N}_{2} \mathrm{O}$ are $284.725 \mathrm{ppmv}$, 790.979 ppbv, and 275.425 ppbv respectively, CFC-11, CFC12 and volcanic aerosols are assumed to be zero). In terms of energy balance and model stability, the global mean topof-atmosphere (TOA) net radiation flux over piControl period is $0.88 \mathrm{~W} \mathrm{~m}^{-2}$, while the global mean surface net radiation flux is $0.86 \mathrm{~W} \mathrm{~m}^{-2}$. The global mean sea surface temperature over piControl period is $17.69^{\circ} \mathrm{C}$ with a warming drift of $0.02^{\circ} \mathrm{C}$ per century (Fig. 1). The historical simulation is initialized with the model states of 1850 year from piControl simulation, and forced with natural variation of solar radiation (Lean et al., 2005; Wang et al., 2005), anthropogenic changes in greenhouse gases concentrations, stratospheric sulphate aerosol concentrations from explosive volcanoes (Ammann et al., 2003), and aerosol concentrations of sulfate, black and organic carbon, dust and sea salt according to Lamarque et al. (2010). Note that there is no land-cover change related to (anthropogenic) land use because the vegetation distributions evolve according to the model-simulated climate, and the areal fraction of non-vegetated regions (lake, wetland, glacier and urban) are fixed according to the Global Land Cover Characterization (GLCC) Database. Therefore, changes in physical and biogeochemical properties of the vegetation due to actual land-cover changes are excluded by design.

\section{General model performance}

To systematically evaluate the general performance of BNUESM, we use the Taylor diagram (Taylor, 2001; Gleckler et al., 2008), which relates the "centered" root-mean square (RMS) error, the pattern correlation and the standard deviation of particular climate fields. We selected 24 fields (Table 1) and compared model simulations with two different reference data sets (only one data set was available for gross primary production over land and surface $\mathrm{CO}_{2}$ flux over ocean). The selection rationale for the fields and reference data sets follows Gleckler et al. (2008), where most 
of reference data sets are briefly described. One notable difference is that we use ERA-Interim (Dee et al., 2011) and JRA-55 (Ebita et al., 2011) reanalysis data instead of ERA40 and NCEP to reflect recent advances in reanalysis systems. We use estimates of specific humidity from National Aeronautics and Space Administration (NASA) Modern Era Retrospective analysis for Research and Applications (MERRA, Rienecker et al., 2011) instead of the Atmospheric Infrared Sounder (AIRS) experiment, as Tian et al. (2013) indicated MERRA specific humidity probably has a smaller uncertainty than the AIRS data set. The International Satellite Cloud Climatology Project (ISCCP, Rossow and Schiffer, 1999; Rossow and Dueñas, 2004) D2 and CLOUDSAT (L'Ecuyer et al., 2008) data sets are used to examine the total cloud cover. The Clouds and the Earth's Radiant Energy System - Energy Balanced and Filled (CERES-EBAF) data set (Loeb et al., 2009) is used instead of the CERES observations, because the energy balanced characteristics of CERESEBAF made it more suitable for the near balanced energetics of the earth system. Two carbon cycle fields (gpp and fgco2) were added to fill the gap between climate system model and earth system model. The reference data used to examine gross primary production (gpp) over land is FLUXNET Model Tree Ensembles (FLUXNET-MTE) estimates (Jung et al., 2011), which are restricted to vegetated land surface. The reference data used to examine surface $\mathrm{CO}_{2}$ flux over ocean (fgco2) is from Lamont-Doherty Earth Observatory (LDEO, Takahashi et al., 2009), this climatology data set was created from about 3 million direct observations of seawater $p \mathrm{CO}_{2}$ around the world between 1970 and 2007.

Figure 2 shows six climatological annual-cycle space-time Taylor diagrams for the 24 selected fields in Table 1 for the tropical $\left(20^{\circ} \mathrm{S}-20^{\circ} \mathrm{N}\right)$ and the northern extra-tropical $(20$ $90^{\circ} \mathrm{N}$ ) zones. It is clear from Fig. 2 that the accuracy of the model varies between fields and domains. Some simulated fields over the northern extra-tropics have correlations with the reference data of greater than 0.95 (e.g., zg-500hPa, ta- $850 \mathrm{hPa}$, rlut, rsnt, tos), and most of fields have correlations with the reference data of greater than 0.8 , whereas one field has much lower correlation of 0.38 (fgco2 over the northern extra-tropics). The amplitude of spatial and temporal variability simulated by the model is reasonably close to that of observationally based reference data. The normalized standard deviations between the simulation and the reference data of most fields have a bias of less than 0.25 , and several fields have a bias of less than 0.1 (e.g., ta- $850 \mathrm{hPa}$, hus850hPa, rlut, rsnt, psl, tos). One outlier in Fig. 2 (NHEX G3 and TROP G3) is the sensible heat flux over ocean (hfss) examined with National Oceanography Centre, Southampton (NOCS) reference data (Josey et al., 1999). The model shows better skills when compared to ERA-Interim reanalysis, although the pattern correlations against two reference data sets are both of about 0.6 . Previous studies suggest that there are large uncertainties in NOCS data set, and their pattern has better agreement with reanalysis products than the magnitude
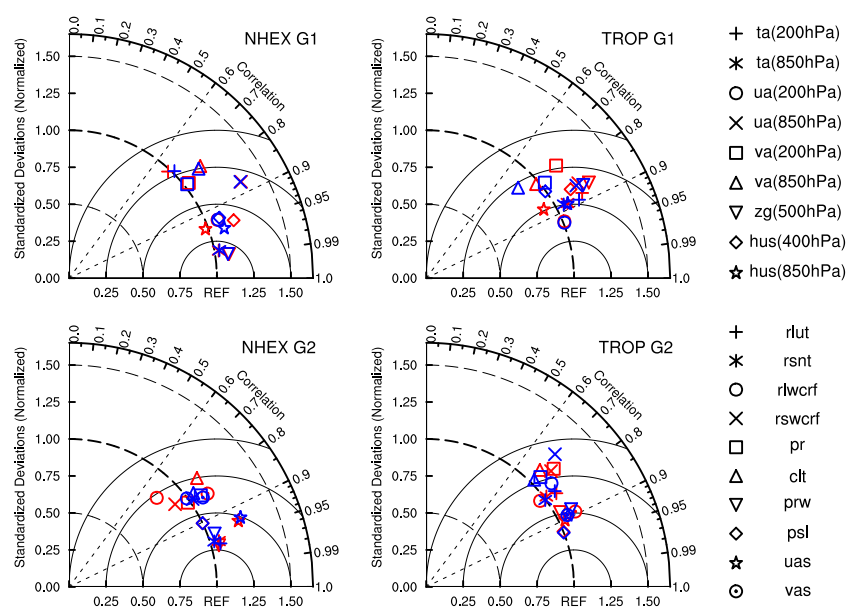

$\begin{array}{cc}+ & \text { rlut } \\ * & \text { rsnt } \\ \circ & \text { rlwcrt } \\ \times & \text { rswcr } \\ \square & \text { pr } \\ \Delta & \mathrm{clt} \\ \nabla & \text { prw } \\ \diamond & \text { psl } \\ \forall & \text { uas } \\ \odot & \text { vas }\end{array}$
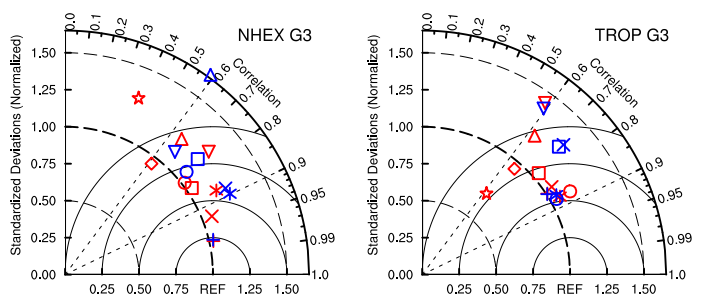

$\begin{array}{cc}+ & \text { tos } \\ * & \text { tauu } \\ 0 & \text { tauv } \\ \times & \text { hfls(ocn) } \\ \square & \text { hfls(Ind) } \\ \Delta & \text { hfss }(\text { ocn }) \\ \nabla & \text { hfss(Ind) } \\ \diamond & \text { gpp } \\ \star & \text { fgco2 }\end{array}$

Figure 2. Multivariate Taylor diagrams of the 20th century annual cycle climatological (1986-2005) for the tropical $\left(20^{\circ} \mathrm{S}-20^{\circ} \mathrm{N}\right.$, TROP) and the northern extra-tropical $\left(20-90^{\circ} \mathrm{N}, \mathrm{NHEX}\right)$ zones. Each field is normalized by the corresponding standard deviation of the reference data, which allows multiple fields to be shown in each sub-figure. Red/Blue markers represent the simulation field evaluated against the Reference1/Reference 2 data defined in Table 1.

of their fluxes (e.g., Taylor, 2000). In general, most of fields over the tropics are closer to reference data than those over the northern extra-tropics in Taylor diagrams, but some fields with relatively high correlations in the northern extra-tropics have a lower skill in the tropics. These features are consistent with Gleckler et al. (2008).

\section{Climatology in the late 20th century}

\subsection{Atmospheric mean state}

Figure 3 shows the zonally averaged mean atmospheric temperature, zonal wind and specific humidity for the historical simulation of the BNU-ESM and its deviations from the ERA-Interim reanalysis (Dee et al., 2011). The air temperature in the troposphere is in general cold for both boreal summer and winter, especially during the boreal summer (Fig. 3a). Near the polar tropopause (about $250 \mathrm{hPa}$ ) there is a relatively large cold bias up to $8 \mathrm{~K}$ over the Arctic during JJA, and up to $10 \mathrm{~K}$ over the Antarctica during DecemberFebruary (DJF). This tropospheric cold bias is one common problem in many CMIP5 models (Charlton-Perez et al., 2013; Tian et al., 2013). In the lower polar troposphere 


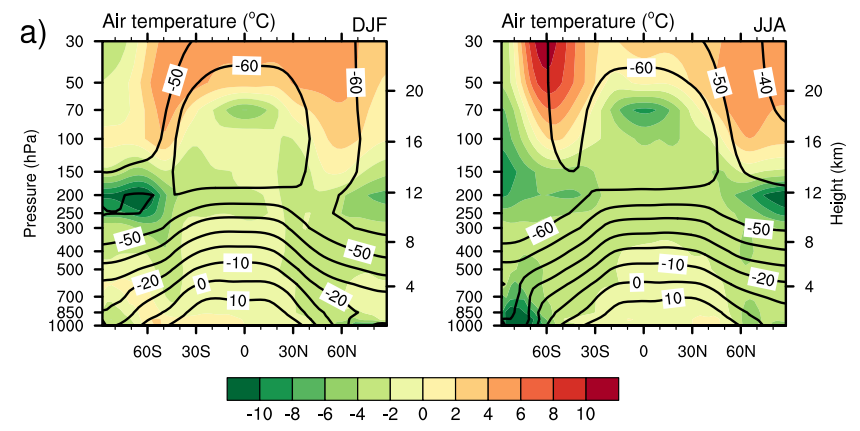

upper tropopause the model overestimates the easterly velocities, the largest biases occur at roughly $50 \mathrm{hPa}$.

Figure $3 \mathrm{c}$ shows the modeled zonally averaged specific humidity and their differences relative to the ERA-Interim reanalysis shown as percentages because the relative error provides a better measure of the water vapor's impact on the radiative transfer than does the absolute errors (Soden et al., 2005). The model can simulate the strong meridional and vertical gradients in tropospheric specific humidity that decrease with both latitude and altitude. For example, the specific humidity decreases from around $14 \mathrm{~g} \mathrm{~kg}^{-1}$ at $1000 \mathrm{hPa}$ near the equator to around $1 \mathrm{~g} \mathrm{~kg}^{-1}$ at $1000 \mathrm{hPa}$ near the poles and around $0.5 \mathrm{~g} \mathrm{~kg}^{-1}$ at $300 \mathrm{hPa}$ over the equator. In comparison with ERA-Interim reanalysis, the model has a moist tendency in the southern tropical upper troposphere (above $700 \mathrm{hPa}$ ) and a slightly dry tendency in the tropical lower troposphere. In terms of relative difference, the model's dry bias in the tropical lower troposphere approaches $15 \%$, and the wet bias in the tropical upper troposphere approaches $50 \%$. This humidity bias pattern is also presented in many CMIP5 models (Tian et al., 2013).

Clouds are always a major source of uncertainty in cli-

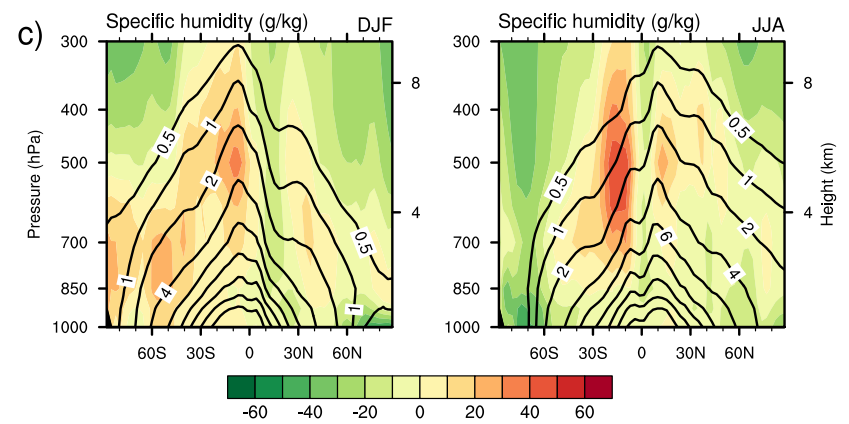

Figure 3. Zonally averaged air temperature (a), zonal wind (b) and specific humidity (c) climatology from BNU-ESM historical simulation (black contours) and bias relative to the ERA-Interim climatology (color filled, color bar is of same units except as \% for specific humidity) for 1986-2005.

during JJA, there is a notable cold bias over the Antarctic. In the stratosphere, the very low winter temperature at $50 \mathrm{hPa}$ in the Southern Hemisphere associated with the polar night jet is overestimated in the model.

With respect to zonally averaged winds (Fig. 3b), the seasonal mitigation of the northern tropospheric jet is well captured in the simulation, but the westerlies at $200 \mathrm{hPa}$ in this jet are too strong by up to $4 \mathrm{~m} \mathrm{~s}^{-1}$ during DJF and $8 \mathrm{~m} \mathrm{~s}^{-1}$ during JJA compared with ERA-Interim reanalysis. The southern tropospheric jet during DJF is also too strong by up to $12 \mathrm{~m} \mathrm{~s}^{-1}$, while the westerlies from the surface to about $100 \mathrm{hPa}$ at $60^{\circ} \mathrm{S}$ during DJF are weak relative to the reanalysis. The westerly wind maximum in the Southern Hemisphere during JJA extends upward into the stratosphere at higher latitudes as is observed. In the stratosphere, the polar-night jets in both hemispheres are shifted slightly polewards relative to the reanalysis. Over the equator in the mate models. In BNU-ESM the total cloud fraction is generally underestimated (Fig. 4a), the global mean value for the years 1976-2005 of the historical simulation gives a bias of $-14 \%$ with a root-mean-square error (RMSE) of $18 \%$ compared with the ISCCP observational data set. A notable exception is Antarctica where there are too many clouds. The tropical central eastern Pacific and southern Africa also have more clouds than observations. The latitudinal averaged cloud fraction bias within the tropics and subtropics is much lower than at higher latitudes (Fig. 4b), and is similar to results from the original CAM3.5 and CAM4 at $2^{\circ} \times 2^{\circ}$ horizontal resolution (Neale et al., 2013). At the same time, the liquid water in clouds over ocean is generally exaggerated in the simulation (Fig. 4c), and is particularly pronounced in the extratropical storm track regions.

Clouds have a significant impact on the global radiative balance that is often assessed using TOA shortwave cloud forcing (SWCF) and long-wave cloud forcing (LWCF) (Ramanathan et al., 1989). In BNU-ESM, the simulated shortwave cooling effect of clouds is too strong in the tropics and too weak in the mid-latitudes (Fig. 5b), especially over oceans, these biases are common in climate models (Trenberth and Fasullo, 2010). BNU-ESM also overestimates LWCF in the tropics due to the presence of a double Intertropical Convergence Zone (ITCZ) (Fig. 5d), and it largely offsets the bias of SWCF in the tropics. In AMIP simulation with sea surface temperature and sea ice boundary conditions specified, the SWCF biases in BNU-ESM (not shown) resemble that in CAM4, except for Eurasian continent (Kay et al., 2012). Over Eurasia, BNU-ESM simulates moderate shortwave cooling effects, while CAM4 simulates opposite warming effects. In South Africa and Amazon regions, both models exhibit strong shortwave cloud cooling effects. 
(a) Total cloud fraction biases [\%]

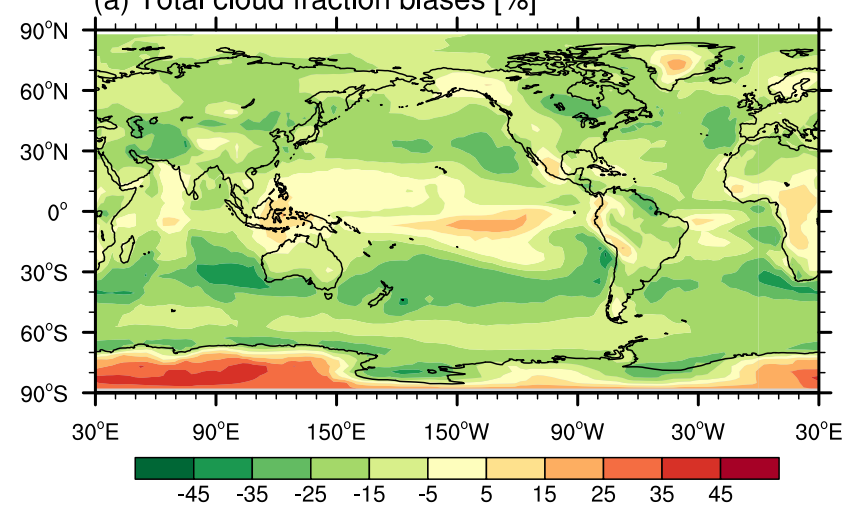

(b) Zonally averaged total cloud fraction [\%]

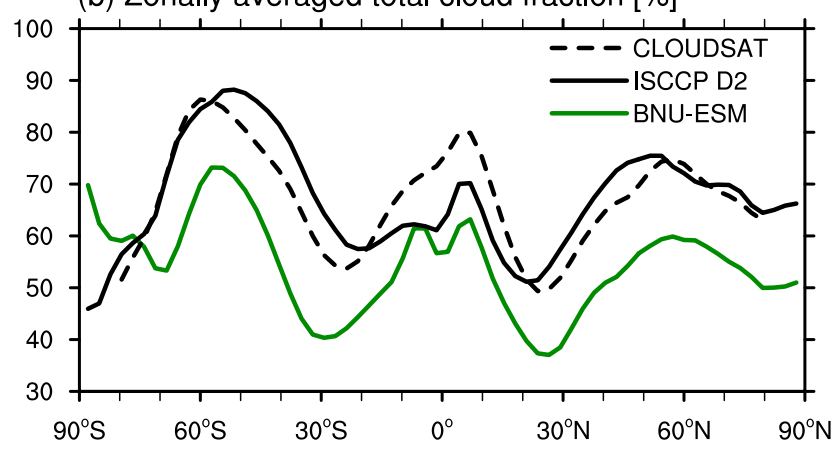

(c) Zonally averaged oceanic cloud LWP $\left[\mathrm{g} / \mathrm{m}^{2}\right]$

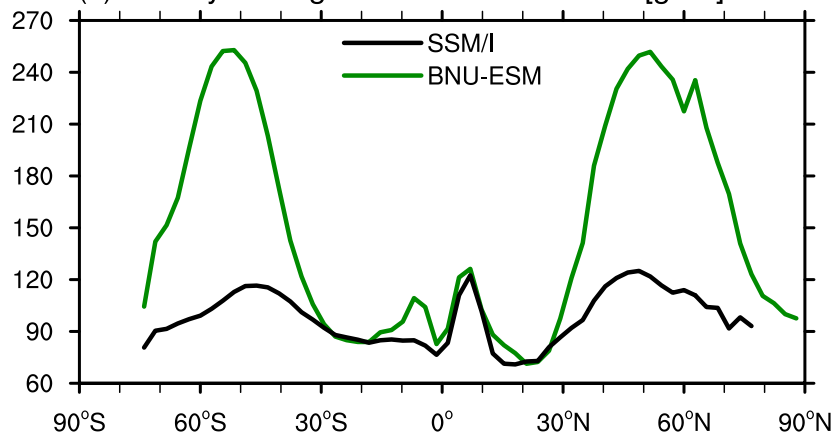

Figure 4. (a) Total cloud fraction bias relative to ISCCP D2 retrievals (Rossow and Schiffer, 1999; Rossow and Dueñas, 2004). (b) Zonally averaged total cloud fraction compared with ISCCP D2 retrievals and CLOUDSAT retrievals (L'Ecuyer et al., 2008). (c) Zonally averaged total liquid water path (LWP) compared with Special Sensor Microwave/Imager (SSM/I) retrievals (Wentz, 2000, 2013) over oceans.

\subsection{Surface temperature and precipitation}

The mean observed and modeled climatological annual cycles of surface-air temperature and precipitation for nine representative land regions are shown in Figs. 6 and 7. The most prominent differences from observations in modeled surface-air temperature are a positive bias in Europe of up to $4^{\circ} \mathrm{C}$ and negative bias in Eastern Siberia up to nearly $7^{\circ} \mathrm{C}$. In Central Canada, China, and India, the biases are relatively small. In addition to Europe, eight of nine regions exhibit cold biases in annual mean surface-air temperature, and the model generally underestimates the annual temperature over the global land area (excluding Antarctica) by $-0.47^{\circ} \mathrm{C}\left(-0.28^{\circ} \mathrm{C}\right)$ with an RMSE of $2.25^{\circ} \mathrm{C}\left(2.40^{\circ} \mathrm{C}\right)$ compared with CRU TS3.1 (Matsuura and Willmott, MW) data. Compared with two observational precipitation data sets, BNU-ESM has a wet bias at high latitudes. Excessive rainfall during winter seasons in Europe results from too strong mid-latitude westerlies, in particular over the North Atlantic, which carry moist maritime air to the continent. The wet season precipitation in the Amazon exhibits a dry bias, and this tendency extends to August. In Southeastern Asia, the monsoon rainfall in India is more realistic than in China; this is consistent with Sabeerali et al. (2013), who found that the BNU-ESM can simulate a climatologically realistic spatial pattern of June to September precipitation over the Asian summer monsoon region. Globally, BNUESM overestimates the annual precipitation over the land (excluding Antarctica) by $0.47 \mathrm{~mm} \mathrm{day}^{-1}\left(0.44 \mathrm{~mm} \mathrm{day}^{-1}\right)$ with a RMSE of $1.42 \mathrm{~mm} \mathrm{day}^{-1}\left(1.33 \mathrm{~mm} \mathrm{day}^{-1}\right)$ compared with CMAP (MW) data. These regional biases may cause dynamic vegetation models in BNU-ESM to produce unrealistic vegetation in affected regions.

In Fig. 8, global surface temperature for the period 19762005 of historical simulation is compared with observations. The globally averaged bias is $-0.17^{\circ} \mathrm{C}$ with a RMSE of $1.83^{\circ} \mathrm{C}$. Over ocean, positive sea surface temperature (SST) biases are seen in the major eastern coastal upwelling regions; probably due to coastal winds that are not favorable for upwelling or underestimation of stratocumulus cloud cover, which is also an issue with other models (e.g., Washington et al., 2000; Roberts et al., 2004; Lin, 2007; Gent et al., 2011). Negative SST biases are mainly found in South Atlantic, South Indian, and subpolar North Pacific Oceans. Another notable negative SST bias is seen in a narrow region associated with East Greenland and Labrador cold currents. In South Atlantic and South Indian Oceans, a tendency for negative SST biases along the northern flank of the Antarctic Circumpolar Current (ACC) are mostly due to insufficient southward transport of heat out of the tropics and a positioning error of the ACC caused by equatorward shift of the westerlies; although there is a small positive bias of the shortwave cloud radiation effect at the cold band between 40 and $50^{\circ} \mathrm{S}$ (Fig. 5b). Gupta et al. (2009) noted that relatively small errors in the position of the ACC lead to more obvious biases in the SST. Over continents, the temperature biases are likely consistent with cloud fraction and TOA shortwave cloud forcing (SWCF) biases (Figs. 8b and 5b). Such as the negative temperature bias over South Africa is likely linked to the negative SWCF bias and excessive cloud fraction, and the positive temperature bias over central USA is probably linked to less cloud fraction (Ma et al., 2014). 

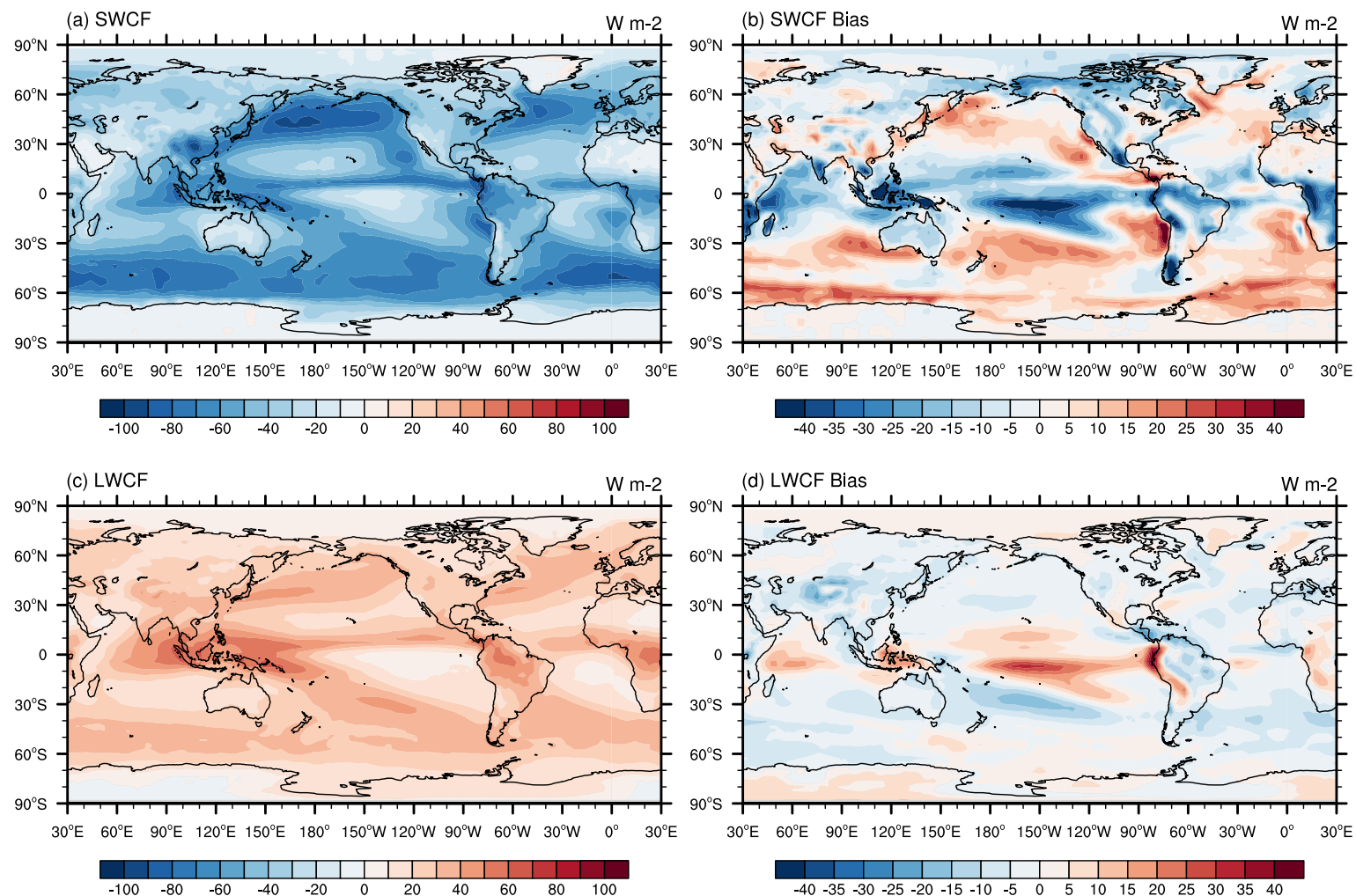

Figure 5. Global map of shortwave cloud forcing (SWCF) and long-wave cloud forcing (LWCF) the following: (a) SWCF of observed CERES-EBAF, (b) BNU-ESM SWCF bias relative to CERES-EBAF, (c) LWCF of observed CERES-EBAF, (d) BNU-ESM LWCF bias relative to CERES-EBAF.

The global average precipitation in BNU-ESM is $0.18 \mathrm{~mm} \mathrm{day}^{-1}$ larger over the period of 1979-2005 year (Fig. 9) than the Global Precipitation Climatology Project (GPCP) data set, which combines surface observations and satellite precipitation data (Adler et al., 2003). While the GPCP data has been claimed to be an underestimate over ocean by Trenberth et al. (2007), the magnitude of tropical precipitation is clearly overestimated by BNU-ESM. In common with many climate models (e.g., Li and Xie, 2014; Lin, 2007), we note a bias in precipitation, characterized by a double Intertropical Convergence Zone (ITCZ) structure over much of the Tropics. This produces excess precipitation over the Northern Hemisphere's ITCZ, Southern Hemisphere's South Pacific convergence zone (SPCZ), the Maritime Continent and the tropical Indian Ocean, together with insufficient precipitation over the equatorial Pacific. BNUESM displays the characteristic pattern of the double ITCZ problem with too much precipitation in the central Pacific near $5^{\circ} \mathrm{S}$ and too little precipitation in the west and central Pacific between 15 and $30^{\circ} \mathrm{S}$ which is similar to CCSM4 (Gent et al., 2011). BNU-ESM underestimates precipitation at $5^{\circ} \mathrm{N}$ latitude but overestimates it along the $5^{\circ} \mathrm{S}$ parallel in the tropical Atlantic. Compared with observations, the BNU-ESM develops too weak a latitudinal asymmetry in tropical precipitation and SST over the eastern Pacific and
Atlantic Oceans. The negative precipitation bias in the South and Northwest Atlantic is closely associated with local negative SST biases (Fig. 8). The band of excessive precipitation over the Southern Ocean between the southernmost of Southern Africa (about at $35^{\circ} \mathrm{S}, 30^{\circ} \mathrm{E}$ ) to southwest of Australian is consistent with the spatial pattern of warm SST biases and is along the northern flank of a cold SST bias, which probably produces more convective precipitation. Over continents, there is excessive precipitation in India, northern China, western USA, South Africa and west coast of South America, and less precipitation in southern China and Amazon.

The frequency and intensity of precipitation in the model is highly dependent on the formulation of the convection parameterization (Wilcox and Donner, 2007). Figure 10 shows frequency versus daily precipitation rate over land in the tropics between $20^{\circ} \mathrm{N}$ and $20^{\circ} \mathrm{S}$, and compared with the observational estimates from the GPCP 1-degree daily data set (Huffman et al., 2001) and the Tropical Rainfall Measuring Mission (TRMM) satellite observations (Kummerow et al., 2000). It is clear that BNU-ESM produces a realistic number of precipitation events at a wide range of precipitation rates, although the model has a tendency to underestimate extreme precipitation events (over $50 \mathrm{~mm} \mathrm{day}^{-1}$ ). We note that 

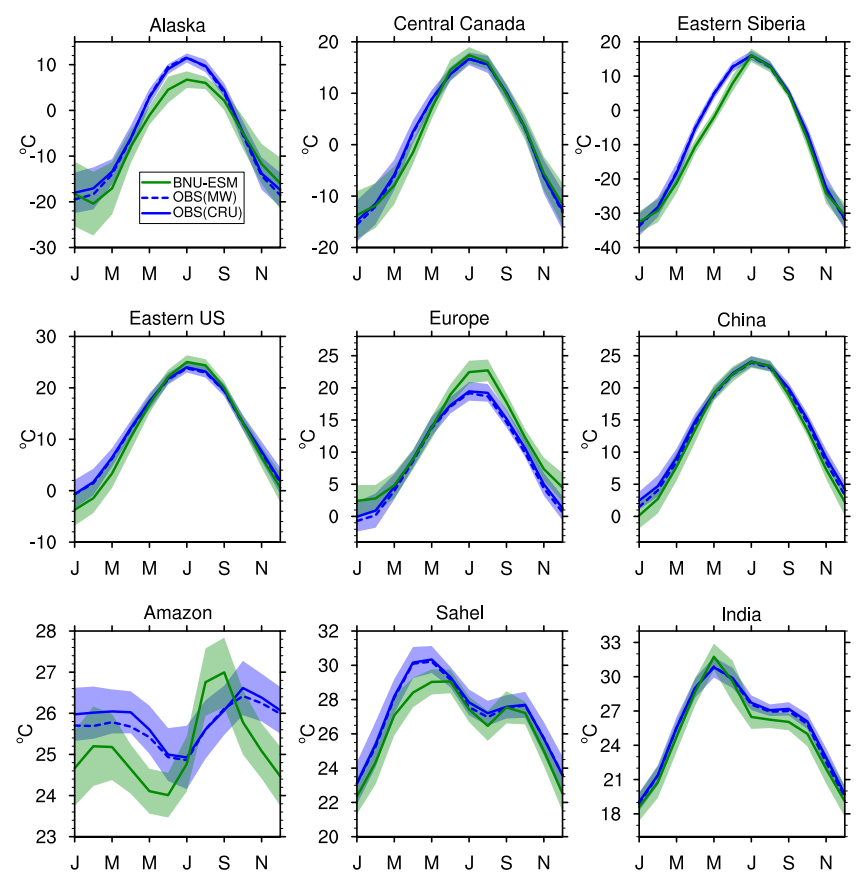

Figure 6. Climatological annual cycle of $2 \mathrm{~m}$ air temperature for selected regions for BNU-ESM and two observational estimates for the period 1976-2005. Color shading indicates interannual variability (standard deviation). MW denotes version $2.01,0.5^{\circ} \times 0.5^{\circ}$ monthly time series from Matsuura and Willmott (2009a). CRU is the Climatic Research Unit $0.5^{\circ} \times 0.5^{\circ}$ TS 3.1 data set (Harris et al., 2014). Regions are defined as follows: Alaska $\left(56-75^{\circ} \mathrm{N}\right.$, $\left.167-141^{\circ} \mathrm{W}\right)$, Central Canada $\left(46-61^{\circ} \mathrm{N}, 123-97^{\circ} \mathrm{W}\right)$, Eastern Siberia $\left(51-66^{\circ} \mathrm{N}, 112-138^{\circ} \mathrm{E}\right)$, eastern United States $\left(27-47^{\circ} \mathrm{N}\right.$, $\left.92-72^{\circ} \mathrm{W}\right)$, Europe $\left(37-57^{\circ} \mathrm{N}, 0-32^{\circ} \mathrm{E}\right)$, China $\left(18-42^{\circ} \mathrm{N}, 100\right.$ $\left.125^{\circ} \mathrm{E}\right)$, Amazon $\left(14^{\circ} \mathrm{S}-5^{\circ} \mathrm{N}, 74-53^{\circ} \mathrm{W}\right)$, Sahel $\left(4-19^{\circ} \mathrm{N}, 0\right.$ $\left.32^{\circ} \mathrm{E}\right)$, and India $\left(4-28^{\circ} \mathrm{N}, 68-94^{\circ} \mathrm{E}\right)$.

CCSM4 also produces similar precipitation characteristics at 1 and $2^{\circ}$ resolutions (Gent et al., 2011).

\subsection{Tropical Pacific SST}

The tropical Pacific SST is closely associated with the El Niño-Southern Oscillation (ENSO), and exerts a strong influence on the East Asian monsoon (Chang et al., 2000; Li et al., 2010). Figure 11 shows the 20th century mean and annual cycle of SSTs along the equator averaged between $2^{\circ} \mathrm{S}$ and $2^{\circ} \mathrm{N}$ in the Pacific Oceans from HadISST observations and the BNU-ESM historical run. The modeled mean SST is colder by about $0.4^{\circ} \mathrm{C}$ than the observations over most of the western Pacific and by nearly $1.3^{\circ} \mathrm{C}$ over the eastern basin, while warmer than reality at both the western and eastern boundaries of the Pacific (Fig. 11a). These biases are caused by the strong easterly winds in the central and western Pacific and weaker zonal wind at the equatorial boundaries of the Pacific, which result in cold and warm SST biases through enhanced or weakened Ekman pumping in these regions. The
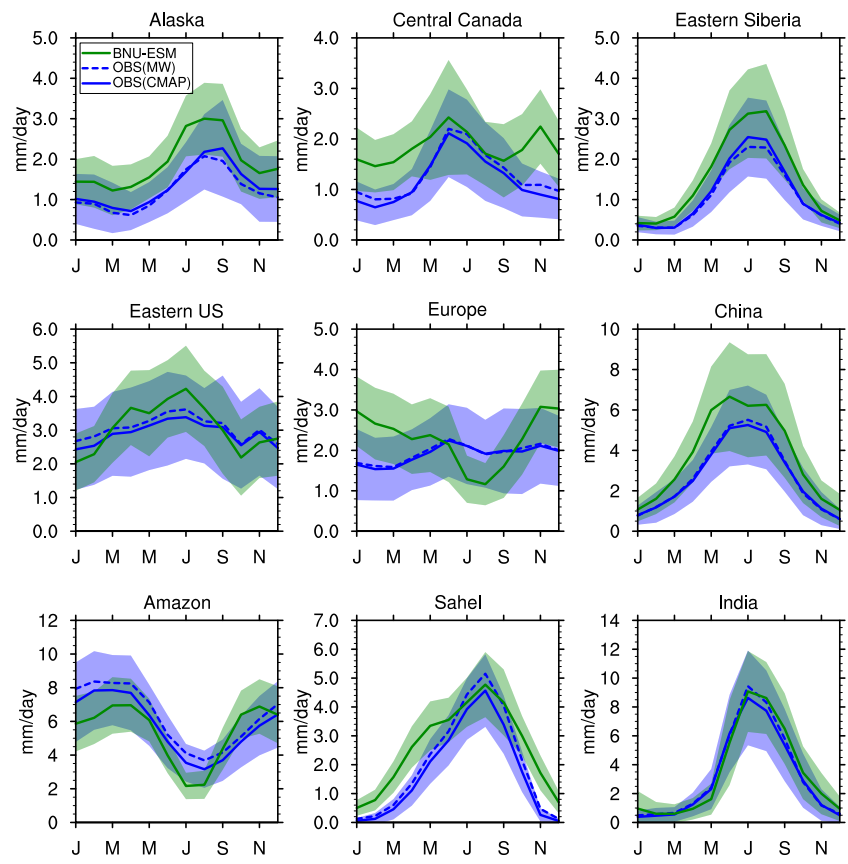

Figure 7. As for Fig. 6, but for precipitation for the period 19792005. Color shading indicates interannual variability (standard deviation). CMAP comes from the Climate Prediction Center (CPC) Merged Analysis of Precipitation 1979-2009 "standard" (no reanalysis data) monthly time series at $2.5^{\circ} \times 2.5^{\circ}$ (Xie and Arkin, 1997). MW is version $2.01,0.5^{\circ} \times 0.5^{\circ}$ monthly time series from Matsuura and Willmott (2009b) for the years 1979-2005.

different cold SST biases in the central eastern Pacific along the equator result in a stronger equatorial westward SST gradient than observed. In terms of seasonal variation, the observations show a dominant annual cycle in SST in the eastern Pacific Ocean, with anomaly patterns propagating westward across the central Pacific (Fig. 11b). BNU-ESM reasonably reproduces features of the annual cycle structure in the eastern Pacific (Fig. 11c); such as its transition phases and the amplitude and the position of the cold tongue, but the warm season peak is 1 month later in the model than in observations. The westward propagation of positive SST anomaly patterns in BNU-ESM is at about the correct speed between April and November, with $0.5^{\circ} \mathrm{C}$ seasonal warming extending to a little west of $160^{\circ} \mathrm{W}$ while the observed anomaly remains east of $160^{\circ} \mathrm{W}$. On the other hand, the observed $0.5^{\circ} \mathrm{C}$ seasonal cooling near the dateline in March is not seen in the model. The semiannual cycle in SST that dominates in the western Pacific in the HadISST observations is also reasonably simulated in BNU-ESM.

\subsection{Sea ice extent}

Sea ice has long been recognized as a critical aspect of the global heat balance. Unrealistic simulation of sea ice usually exposes deficiencies in both atmospheric and oceanic 

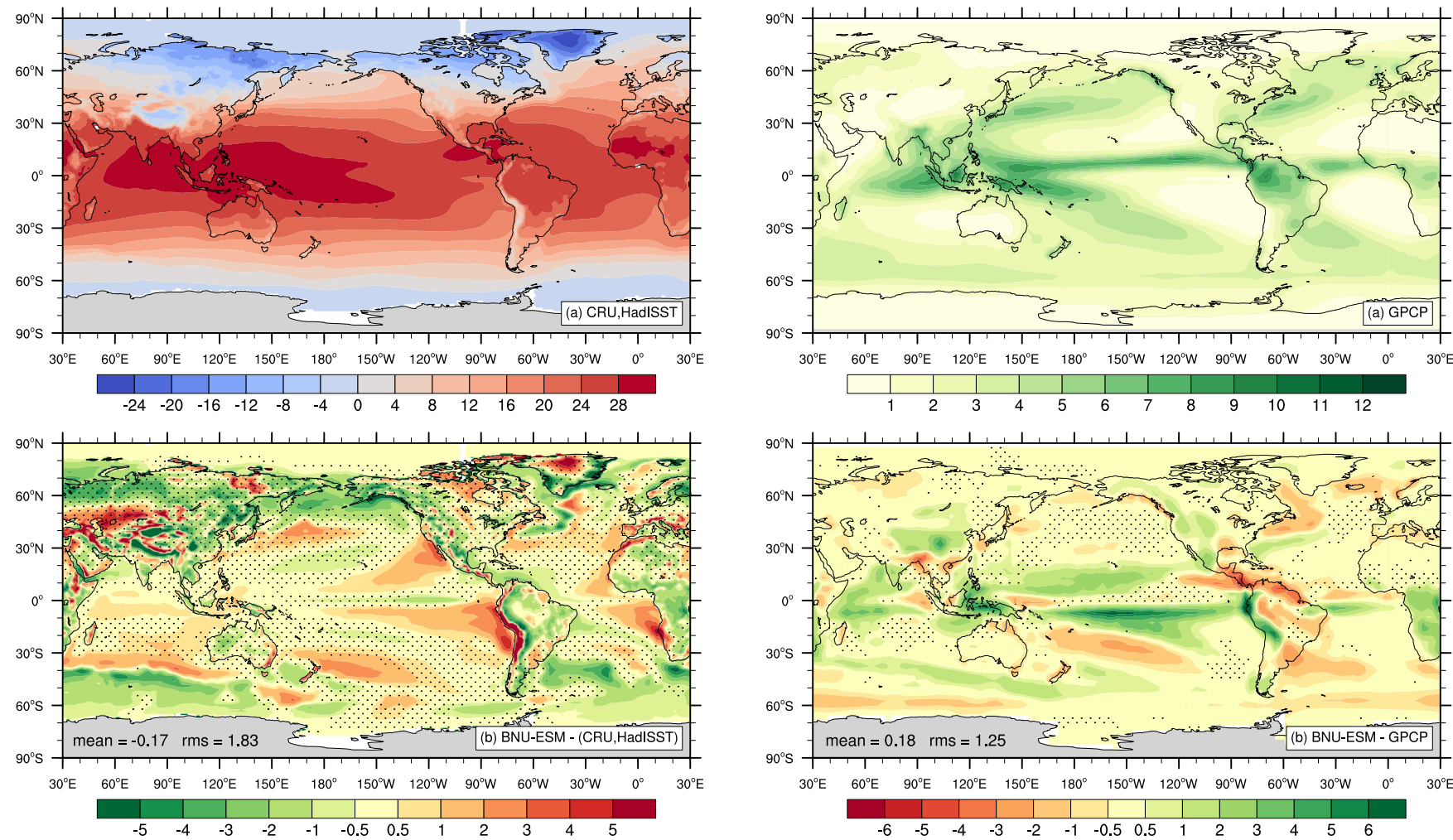

Figure 8. Climatological mean surface temperature from the $0.5^{\circ} \times 0.5^{\circ} \mathrm{CRU}$ TS 3.1 (Harris et al., 2014) and $1^{\circ} \times 1^{\circ}$ HadISST (Rayner et al., 2003) observations for the period 1976-2005 (a). Annual mean surface temperature bias $\left({ }^{\circ} \mathrm{C}\right)$ of BNU-ESM relative to the CRU TS 3.1 and HadISST data sets for the period 19762005 (b). All data sets are regridded to $1^{\circ} \times 1^{\circ}$ resolution. Dotted area indicates non-significant regions at the $95 \%$ confidence level.

forcing (e.g., Losch et al., 2010). The observational data used to evaluate the BNU-ESM is monthly climatological sea ice concentrations from the Special Sensor Microwave Imager (SSM/I) data set (Comiso, 1999), obtained from the National Snow and Ice Data Center (NSIDC). We also use the NSIDC's Sea Ice Index (Fetterer et al., 2002), which contains monthly values of sea ice extent and sea ice area. Figure 12 shows the climatological sea ice concentration in the Arctic and Antarctica for the period 1979-2005 of BNU-ESM historical simulation, and the solid black lines are the $15 \%$ mean concentration values from SSM/I satellite observations. The sea ice extent is overestimated in March (Fig. 12a) and slightly underestimated in September (Fig. 12b) following the summer in the Northern Hemisphere (the average mean sea ice extents of March and September are 18.46 and 5.87 million $\mathrm{km}^{2}$, while the NSIDC sea ice extents for the same periods are 15.48 and 6.67 million $\mathrm{km}^{2}$.). In the Southern Hemisphere both March (Fig. 12c) and September (Fig. 12d) extents are overestimated (the average mean sea ice extents of March and September are 4.96 and 25.94 million $\mathrm{km}^{2}$, while the NSIDC sea ice extents are

Figure 9. Climatological mean precipitation from the GPCP (Adler et al., 2003) observations (a) and annual mean precipitation bias $\left(\mathrm{mm} \mathrm{day}^{-1}\right.$ ) of BNU-ESM relative to the GPCP climatology for the period 1979-2005 (b). Dotted area indicates non-significant regions at the $95 \%$ confidence level.

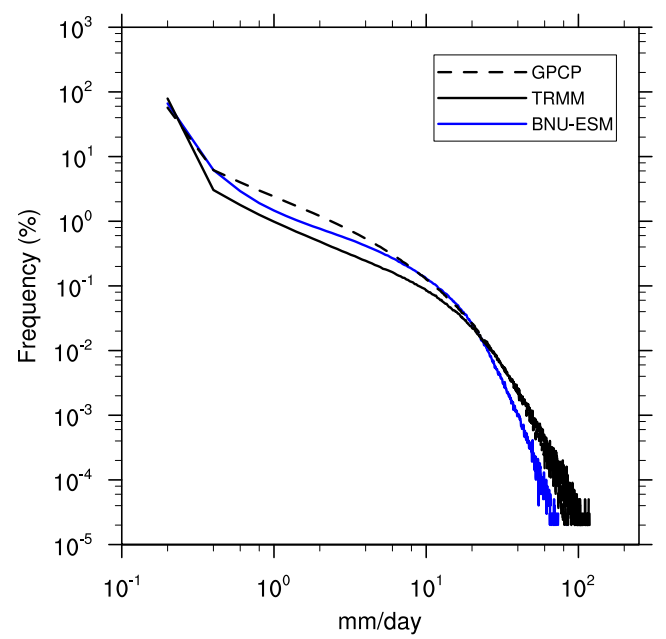

Figure 10. Frequency $(\%)$ of daily precipitation rate over land between $20^{\circ} \mathrm{N}$ and $20^{\circ} \mathrm{S}$ from BNU-ESM historical simulation over the period 1990-1999, the GPCP 1-degree daily data set and TRMM 3B42 daily observations over the period 1999-2008. All data are regridded to the T42 spectral resolution (approximately $2.81^{\circ} \times 2.81^{\circ}$ transform grid). 
(a) Equatorial Pacific Mean SST

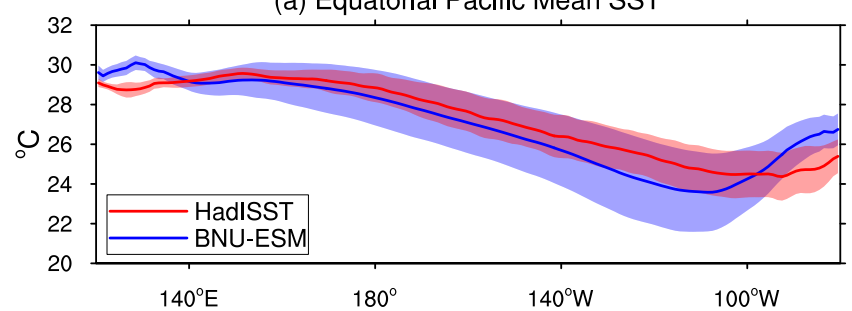

(b) HadISST

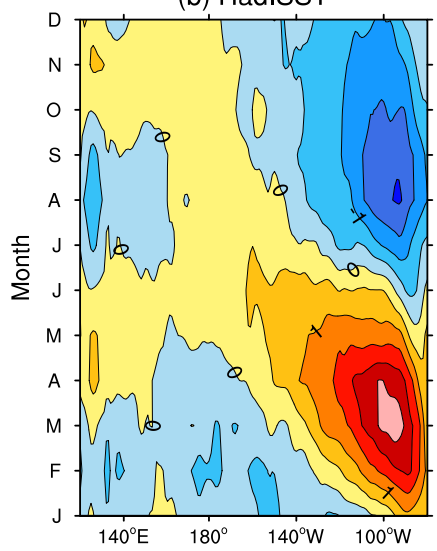

(c) BNU-ESM

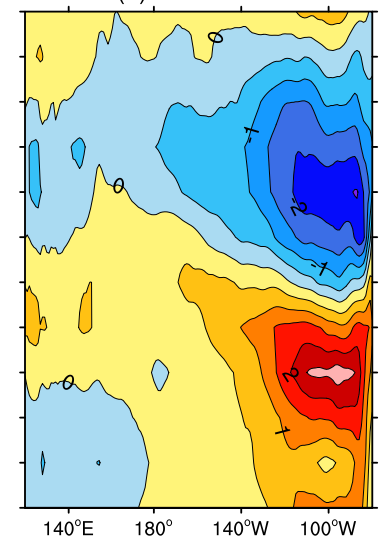

Figure 11. Mean SST $\left({ }^{\circ} \mathrm{C}\right)$ along the equator in the Pacific Ocean (a), color shading indicates interannual variability (standard deviation). Annual cycle of SST anomalies for the period 19762005 from HadISST (b) and the BNU-ESM historical run (c).

4.02 and 18.45 million $\mathrm{km}^{2}$ ). The excessive sea ice extent following the winter in the Northern Hemisphere is mostly due to too much sea ice in the Labrador Sea, Bering Sea, Sea of Okhotsk and adjacent North Pacific. The modeled geographic distribution of ice in the Northern Hemisphere is close to observations in summer. In the Southern Hemisphere, the main overestimation in summer is in Weddell Sea. The too extensive sea ice simulated in both hemispheres is consistent with the cold SST bias found in corresponding areas (Fig. 8). The simulated atmospheric fields are at least partly responsible for the Southern Hemisphere sea ice bias. One notable bias is that the annual average zonal wind stress from about 35 to $55^{\circ} \mathrm{S}$ latitudes over ocean is $23.2 \%$ stronger compared with ERA-Interim reanalysis and $42.8 \%$ stronger compared with NCEP reanalysis, which likely inhibits sufficient southward transport of heat, and contributes to cold surface temperatures that are directly linked to a biased ice extent.

In terms of seasonal cycle of sea ice extent, the simulated Arctic sea ice extent for the period 1980-1999 is within the range of 42 CMIP5 models reported by Flato et al. (2013). In Antarctica, BNU-ESM estimates reasonable sea ice extents for February, but overestimates them in September $\left(26\right.$ million $\mathrm{km}^{2}$ ), which is somewhat above the range of 42 CMIP5 models. BNU-ESM and CCSM/CESM adopt similar sea ice schemes, and both models can simulate both the
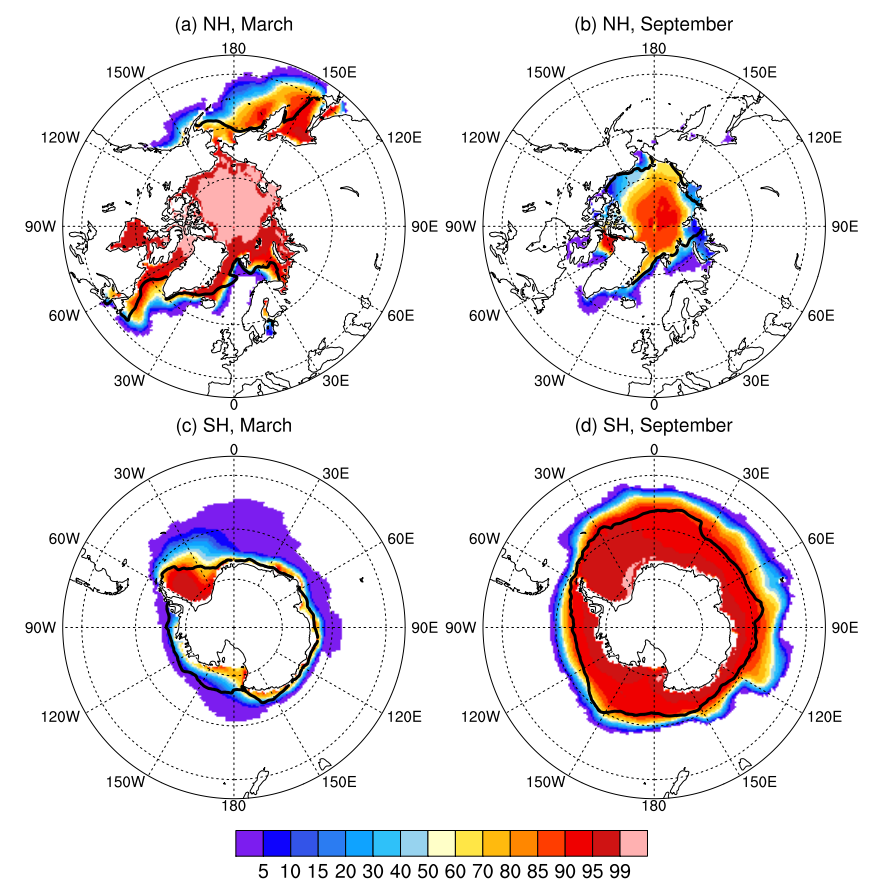

Figure 12. Mean sea ice concentration (\%) over years 1976-2005 of the BNU-ESM historical run for both hemispheres and for March (a, c) and September $(\mathbf{b}, \mathbf{d})$. The solid black lines show the $15 \%$ mean sea ice concentration from SSM/I observations (Comiso, 1999).

September Arctic sea ice extent and the rate of Arctic sea ice decline over recent decades better than many other CMIP5 models (Liu et al., 2013). While for Antarctica BNU-ESM and CCSM both have a tendency to overestimate sea ice extent.

\subsection{Ocean meridional overturning circulation}

The meridional overturning circulation (MOC) of the global ocean is a system of surface and deep currents encompassing all ocean basins. It transports large amounts of water, heat, salt, carbon, nutrients and other substances around the globe, and is quite important for the chemical and biological properties of the ocean. The Atlantic MOC (AMOC) is an important part of the system and is responsible for a considerable part of northward oceanic heat transport. Figure 13 shows 30 year means of the global MOC and the AMOC over the 19762005 period of the BNU-ESM historical run; the overall patterns and positions of cells, water masses, and overturning are similar to observed patterns (Lumpkin and Speer, 2007). North Atlantic deep-water circulation can reach most of the ocean bottom between 30 and $60^{\circ} \mathrm{N}$. The maximum overturning of Atlantic water occurs near $35^{\circ} \mathrm{N}$ and is $28.4 \mathrm{~Sv}$ $\left(1 \mathrm{~Sv}=10^{6} \mathrm{~m}^{3} \mathrm{~s}^{-1}\right)$ at a depth of about $1.5 \mathrm{~km}$. Many other models have maximum overturning at a depth of $1 \mathrm{~km}$; the reason for the deeper position in BNU-ESM is not well understood. The maximum annual mean AMOC strength at $26.5^{\circ} \mathrm{N}$ in BNU-ESM is about $25.4 \mathrm{~Sv}$, which is somewhat 


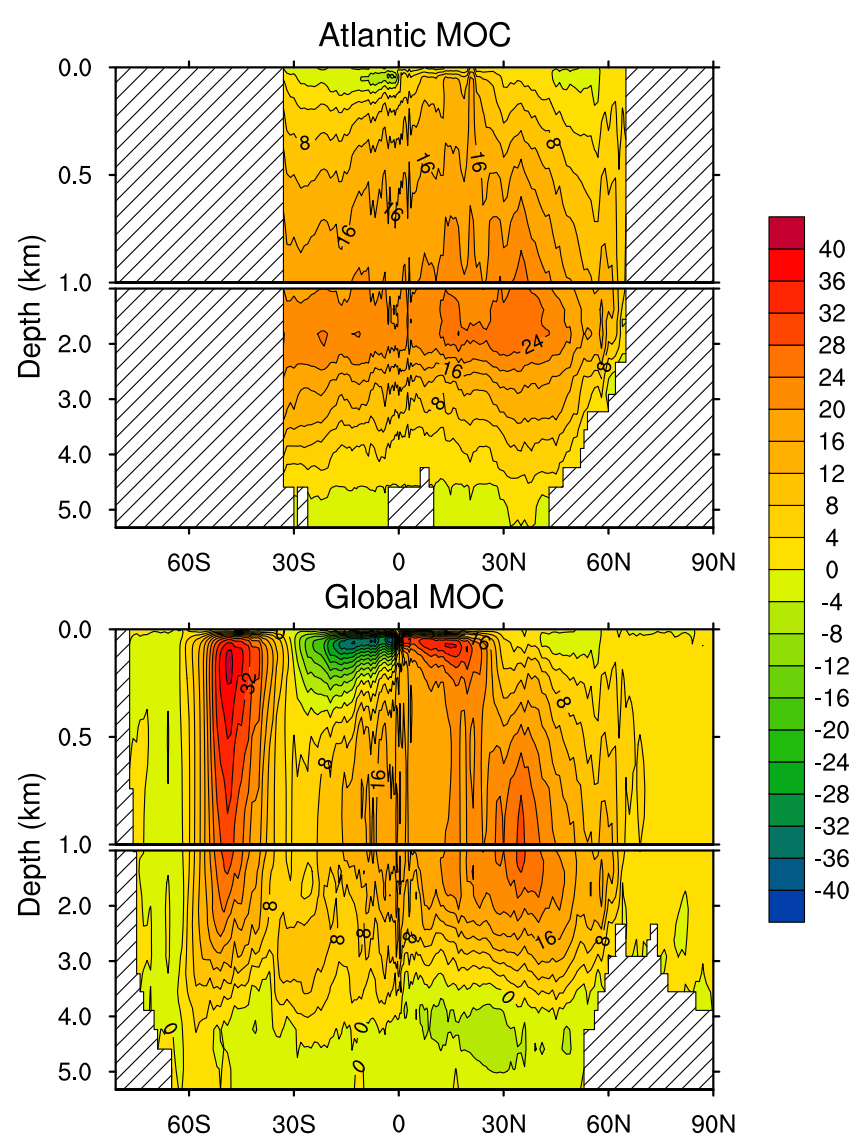

Figure 13. Atlantic meridional overturning circulation (MOC) (Sv) and global MOC (Sv) for the period 1976-2005 from the BNUESM historical run.

above the estimate of $18.7 \pm 4.8 \mathrm{~Sv}$ for the AMOC strength at the same latitude found by the RAPID/MOCHA monitoring array for the years 2004-2011 (Rayner et al., 2011). Over the historical simulation period (1850-2005), the maximum annual mean AMOC strength at $26.5^{\circ} \mathrm{N}$ decreases $12.6 \%$ from 26.9 to $23.5 \mathrm{~Sv}$.

The BNU-ESM global MOC possesses a strong Deacon cell of about $40 \mathrm{~Sv}$ between 60 and $45^{\circ} \mathrm{S}$, which penetrates to $4 \mathrm{~km}$ depth and is a result of increased zonal wind stress driving the ocean. The mean transport of the Antarctic Circumpolar Current (ACC) through Drake Passage is about 101.7 Sv. This is less than the measured value of $134 \pm 11 \mathrm{~Sv}$ (Cunningham et al., 2003) and at the low end of the range of 90-264 Sv from 23 CMIP5 models (Meijers et al., 2012). One reason for weaker ACC transport through the Drake Passage is that the model-simulated westerly wind stress maximum is shifted equatorward. The mean zonal wind stress over ocean is $26 \%$ lower than ERA-Interim reanalysis products at the latitude of the Drake Passage. Antarctic Bottom Water (AABW) is located north of $50^{\circ} \mathrm{S}$ at depths greater than $3.5 \mathrm{~km}$, and the deep MOC in the Southern Hemisphere is about $4 \mathrm{~Sv}$ and weak compared with estimates of $8-9.5 \mathrm{~Sv}$ from observations (Orsi et al., 1999).

\section{Climate variability}

\subsection{Tropical intraseasonal oscillation}

The dominant component of the tropical intraseasonal oscillation (ISO) is the Madden-Julian Oscillation (MJO) (Madden and Julian, 1971, 1972) which affects tropical deep convection and rainfall patterns. During the boreal winter an eastward propagating component affects rainfall over the tropics, while during the boreal summer a northward propagating ISO affects much of southern Asia (e.g., Krishnamurti and Subrahmanyam, 1982; Lau and Chan, 1986; Annamalai and Sperber, 2005; Yang et al., 2008). The MJO plays the prominent role in tropical climate variability, but is still poorly represented in climate models (Lin et al., 2006; Kim et al., 2009; Xavier et al., 2010; Lau and Waliser, 2012; Sperber and Kim, 2012). Here, we adopt the set of community diagnostics developed by the CLIVAR MJO Working Group to examine simulated MJO characteristics. In BNU-ESM, the winter eastward propagation is well detectable in zonal winds at $850 \mathrm{hPa}$ (U850) over a region from the maritime continent to the western Pacific, but is absent over the Indian Ocean and not evident in precipitation (Fig. 14a and b). Meanwhile, the northward propagation in summer can be realistically simulated; particularly in the off-equatorial region from 5 to $20^{\circ} \mathrm{N}$ (Fig. 14c and d). The quadrature relationship between precipitation and U850 is also well reproduced in northward propagation signals, consistent with observations.

The observed MJO (Fig. 15a) exhibits peak power at zonal wavenumber 1 at a period of 30-80 days in both boreal winter and summer (e.g., Weickmann et al., 1985; Kiladis and Weickmann, 1992; Zhang et al., 2006). The power spectrum of BNU-ESM shows that the zonal wave number power distribution is well captured during boreal winter (Fig. 15b); but the eastward propagating power tends to be concentrated at lower than observed frequencies (periods $>80$ days). The power density for westward propagation is overestimated, and consequently the east-west ratio of MJO spectral power is smaller than observed. As with BNUESM, the power spectra maximum produced by CCSM3.5 using its default convection parameterization is also greater than 80 days (Kim et al., 2009), while spectra computed by Zhang and Mu (2005b) for CCM3 adopting the same convection parameterization scheme as BNU-ESM peaks at approximately 40 days. These studies suggest that the ability of a climate model to simulate realistic MJO depends not only on its convective parameterization, but also on interactions between convection and other physical processes in the model. BNU-ESM simulation shows a northward propagating mode of precipitation during boreal summer at wavenumber 1 with a maximum variance between 30 and 50 days (Fig. 15d), but the northward propagating band is weaker than observed (Fig. 15c). Sabeerali et al. (2013) analyzed the boreal summer ISO of BNU-ESM along with 32 CMIP5 models. They found that BNU-ESM is one of six models which captures 

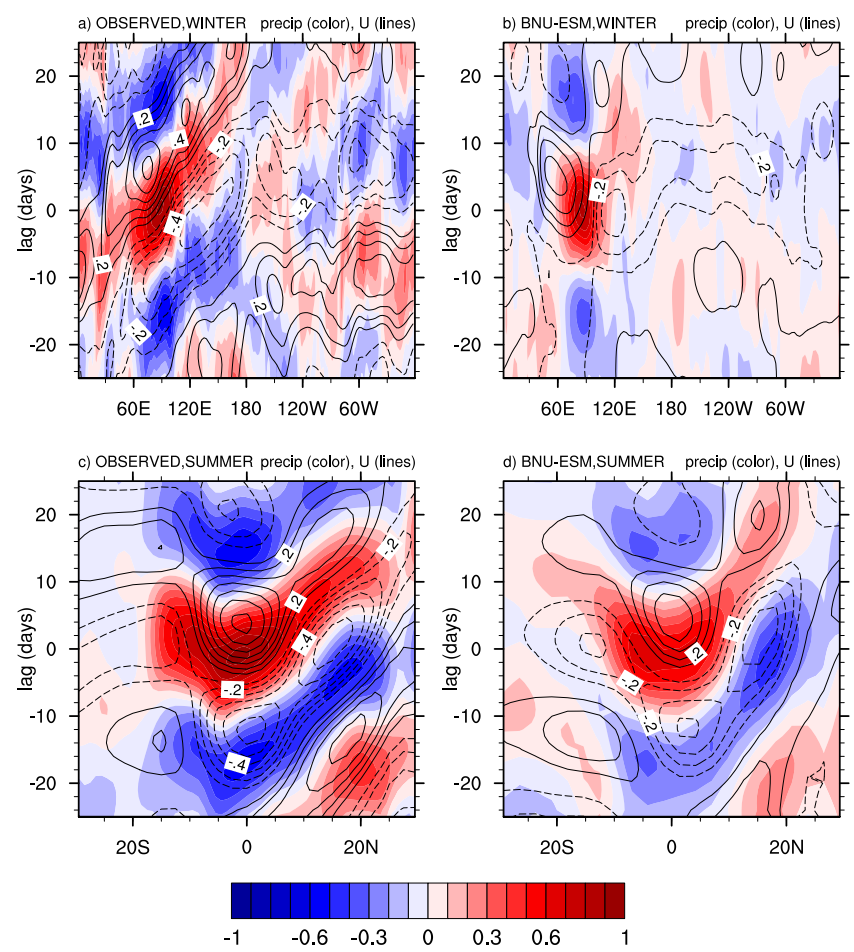

Figure 14. November-April lag-longitude diagram of $10^{\circ} \mathrm{S}-10^{\circ} \mathrm{N}$ averaged intraseasonal precipitation anomalies (colors) and intraseasonal $850 \mathrm{hPa}$ zonal wind anomalies (contours) correlated against intraseasonal precipitation in the Indian Ocean reference region $\left(10^{\circ} \mathrm{S}-5^{\circ} \mathrm{N}, 75^{\circ}-100^{\circ} \mathrm{E}\right)$ for NCEP observation (a) and BNU-ESM (b). May-September lag-latitude diagram of $65^{\circ}-95^{\circ} \mathrm{E}$ averaged intraseasonal precipitation anomalies (colors) and intraseasonal $850 \mathrm{hPa}$ zonal wind anomalies (contours) correlated against intraseasonal precipitation at the Indian Ocean reference region for NCEP observation (c) and BNU-ESM (d). The averaging period is 1980-2005 for BNU-ESM historical run, and 1997-2006 for observations.

the three peak centers of boreal summer ISO variance over the Indian summer monsoon region adequately.

We also compared space-time spectra of daily tropical precipitation from BNU-ESM with observed precipitation estimates from GPCP 1-degree daily data set from 1997 to 2005 using the methodology of Wheeler and Kiladis (1999). Figure 16 shows the results of dividing the symmetric raw spectra by estimates of their background spectra. Kelvin, equatorial Rossby (ER), westward inertia-gravity (WIG) waves and the MJO are readily identified in the observational GPCP symmetric spectra. Signals of convectively coupled Kelvin and ER waves appear in the model, and the spectral signature of the MJO is also represented. In observations there is a clear distinction between eastward power in the MJO range (20 day-80 day) and westward power associated with ER waves. The BNU-ESM model exhibits this distinction to some extent, with the eastward power lying at a constant frequency across all wavenumbers and the westward
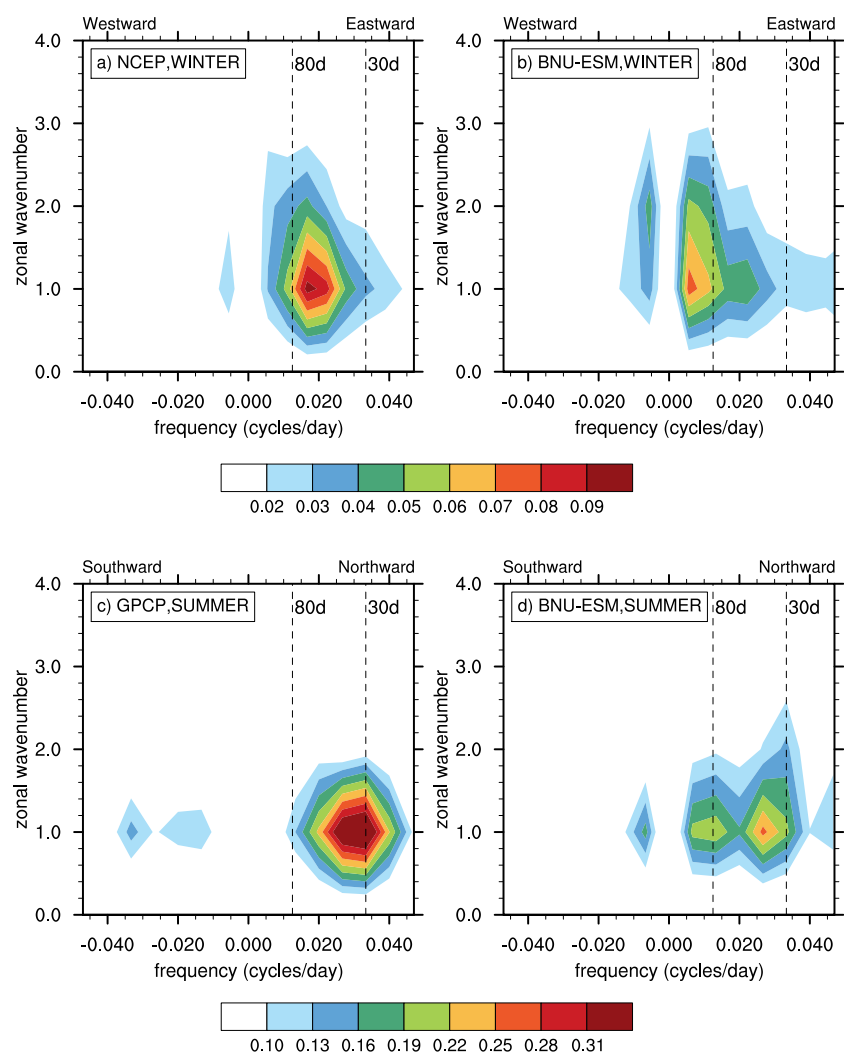

Figure 15. November-April wavenumber-frequency spectra of $10^{\circ} \mathrm{S}-10^{\circ} \mathrm{N}$ averaged daily zonal $850 \mathrm{hPa}$ winds for NCEP observation (a) and BNU-ESM (b). May-September wavenumberfrequency spectra of $15^{\circ} \mathrm{S}-30^{\circ} \mathrm{N}, 65-95^{\circ} \mathrm{E}$ averaged daily precipitation for GPCP observation (c) and BNU-ESM (d). Individual spectra were calculated for each year and then averaged over all years of data. Only the climatological seasonal cycle and time mean for each November-April or May-September segment were removed before calculation of the spectra. The averaging period is 1980-2005 for BNU-ESM historical run, and 1997-2006 for observations.

power lying more along the ER dispersion curves. BNUESM represents signals of convectively coupled equatorial waves (CCEWs) similarly as CCSM4 (Hung et al., 2013), such as the equivalent depth of the waves and the low power of WIG waves (Fig. 4 in Hung et al., 2013). The powers of eastward propagating components near the MJO spatial and temporal scale in BNU-ESM are more distinctive than that of their westward propagating counterparts compared with CCSM4 (Hung et al., 2013).

\subsection{El Niño-Southern Oscillation}

The El Niño-Southern Oscillation (ENSO) phenomenon is the dominant mode of climate variability on seasonal to interannual time scales (Zhang and Levitus, 1997; Wang and Picaut, 2004; Zhang et al., 2013). Bellenger et al. (2013) analyzed several aspects of ENSO from the BNU-ESM, and 


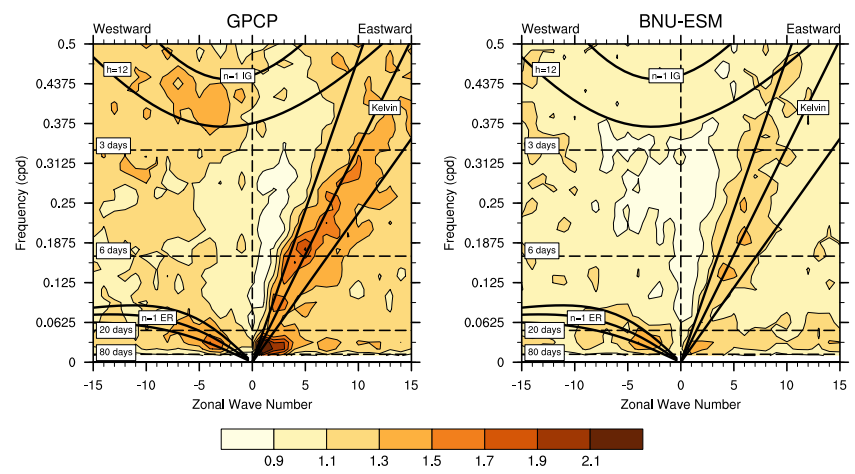

Figure 16. Space-time spectrum of the $15^{\circ} \mathrm{N}-15^{\circ} \mathrm{S}$ symmetric component of precipitation divided by the background spectrum. Superimposed are the dispersion curves of the odd meridional mode numbered equatorial waves for 12,25 , and $50 \mathrm{~m}$ equivalent depths. Frequency spectral width is $1 / 128 \mathrm{cpd}$.

here we present several different aspects of Niño-3.4. Figure 17 shows time series of detrended monthly SST anomalies of the Niño-3.4 region $\left(5^{\circ} \mathrm{S}-5^{\circ} \mathrm{N}, 170-120^{\circ} \mathrm{W}\right)$ for the HadISST observations and BNU-ESM historical simulation for the years 1900-2005, as well as SST anomalies from the corresponding years of BNU-ESM piControl simulation. Overall, the BNU-ESM exhibits strong interdecadal variations in the amplitude and period in the ENSO frequency band. The model overestimates the amplitude of Niño-3.4 SST variability considerably with respect to HadISST observations, with a standard variability $1.47 \mathrm{~K}$ for both the piControl and historical simulations compared with the standard deviation of HadISST of $0.75 \mathrm{~K}$. A well-known characteristic of observed ENSO events is the tendency for phase-locking to the seasonal cycle. The standard deviation of the observed Niño-3.4 SST index maximizes $(0.97 \mathrm{~K})$ in December and reaches a minimum $(0.56 \mathrm{~K})$ in May, and the Niño-3.4 SST index of BNU-ESM historical run also maximizes $(1.71 \mathrm{~K})$ in December and reaches a minimum $(1.21 \mathrm{~K})$ in May. BNUESM exhibits realistic timing of the seasonal cycle with one peak and one minimum, but the amplitude is much stronger than in observations.

Figure 18 shows the power spectra of the normalized time series of Fig. 17 (the detrended SST anomalies normalized by their long-term standard deviation). The observation based Niño-3.4 index has most power between 3 and 7 years, while both BNU-ESM indices have the most prominent variability between 2 and 5 years with a narrow peak at 3.5 years. On timescales longer than 10 year, the piControl and historical simulations have similar power spectra but less power compared with HadISST observations. The presence of variability in the external forcing during the historical simulation does not induce significant changes in decadal and longer period variability.

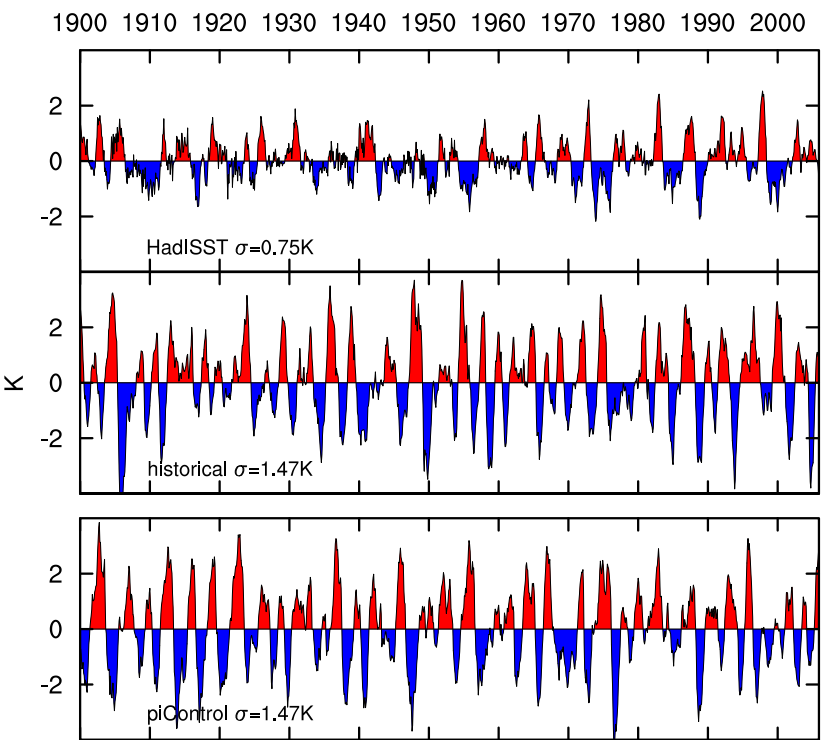

19001910192019301940195019601970198019902000

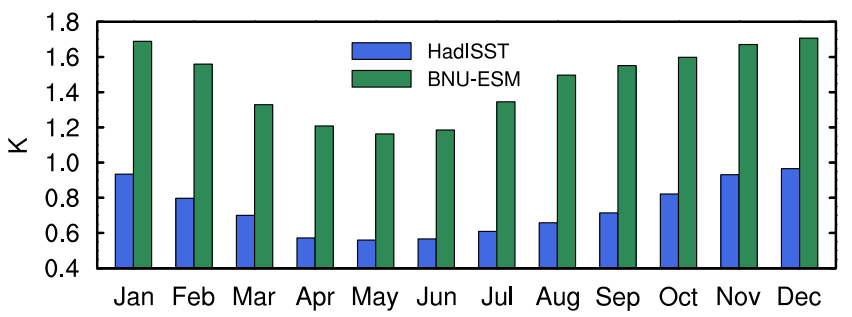

Figure 17. Time series of detrended monthly SST anomalies of the Niño-3.4 region $\left(5^{\circ} \mathrm{S}-5^{\circ} \mathrm{N}, 170-120^{\circ} \mathrm{W}\right)$ from HadISST, the BNU-ESM historical and piControl runs. The anomalies are found by subtracting the monthly means for the whole time series. The bottom sub-figure is standard deviation of monthly Niño-3.4 SST anomalies from HadISST and the BNU-ESM historical run.

Another aspect of the BNU-ESM ENSO historical simulation, shown in Fig. 19, is the correlation of monthly mean Niño-3.4 SST anomalies with global SST anomalies compared with that from HadISST observations. The figure shows a realistic but narrower meridional width of the positive correlations in the central and eastern tropical Pacific. A horseshoe pattern of negative correlations in the western tropical Pacific is seen in HadISST but is less pronounced in the model. The positive correlation in the western part of the Indian Ocean is well simulated in BNU-ESM, but the extension of this positive pattern into the Bay of Bengal, Gulf of Thailand and South China Sea is missing from the model. The correlation patterns in the Atlantic Ocean are similar between HadISST and BNU-ESM, but more pronounced in the model.

The Southern Oscillation is the atmospheric component of El Niño. Figure 20 shows the Southern Oscillation Index (SOI) from BNU-ESM compared to observation. The observed SOI is calculated using station data from Darwin and Tahiti. For the model, areal averages of mean sea-level 


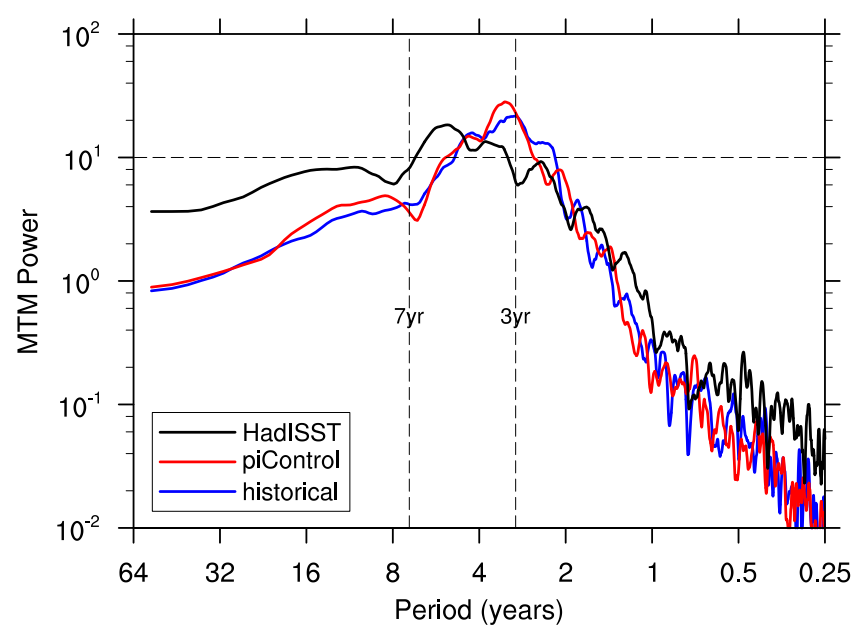

Figure 18. Power spectra of the Niño-3.4 index (the SST anomalies of Fig. 17 normalized with the standard deviation) using the multitaper method (Ghil et al., 2002) with resolution $p=4$ and number of tapers $t=7$.

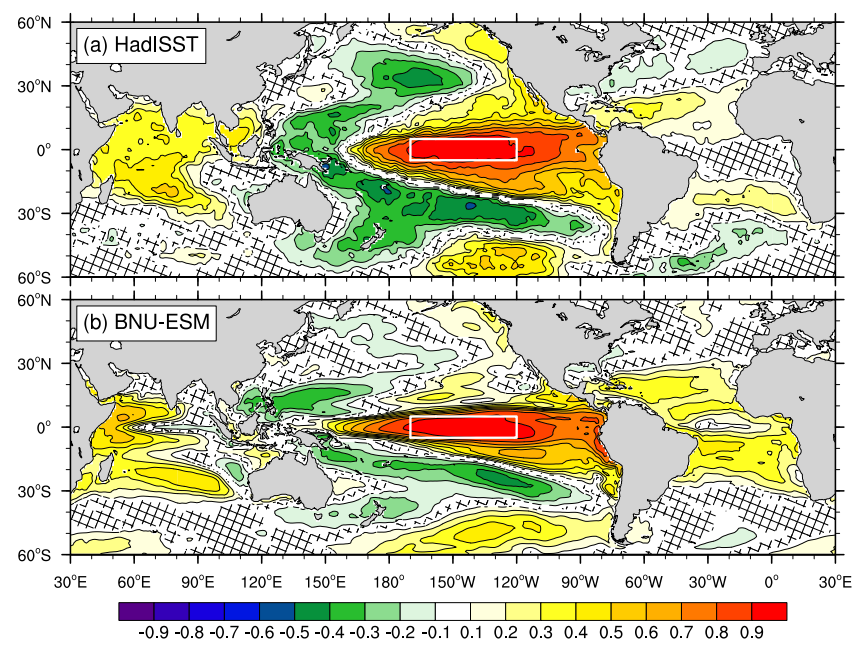

Figure 19. Correlation of monthly mean Niño-3.4 SST anomalies with global SST anomalies for the HadISST and BNU-ESM. The anomalies are found by subtracting the monthly means for the whole time series that span the years 1900-2005. Hatched area indicates regions where the correlation is not significantly different from zero at the $95 \%$ confidence level.

pressure over $125-135^{\circ} \mathrm{E}, 17-7^{\circ} \mathrm{S}$ and $155-145^{\circ} \mathrm{W}, 22-$ $12^{\circ} \mathrm{S}\left(10^{\circ} \times 10^{\circ}\right.$ areas centered close to the Darwin and Tahiti stations) are used. The interannual variability in the modeled SOI due to ENSO events is well reproduced and shows the expected negative correlation with Niño-3.4 SST anomalies (Fig. 17). The modeled regression coefficient between monthly deseasonalized SOI and Niño3.4 SST anomalies is $-0.52 \mathrm{hPa} \mathrm{K}^{-1}$ while the observed is $-1.52 \mathrm{hPa} \mathrm{K}^{-1}$. Hence, the model underestimates the strength of the atmospheric response to ENSO.

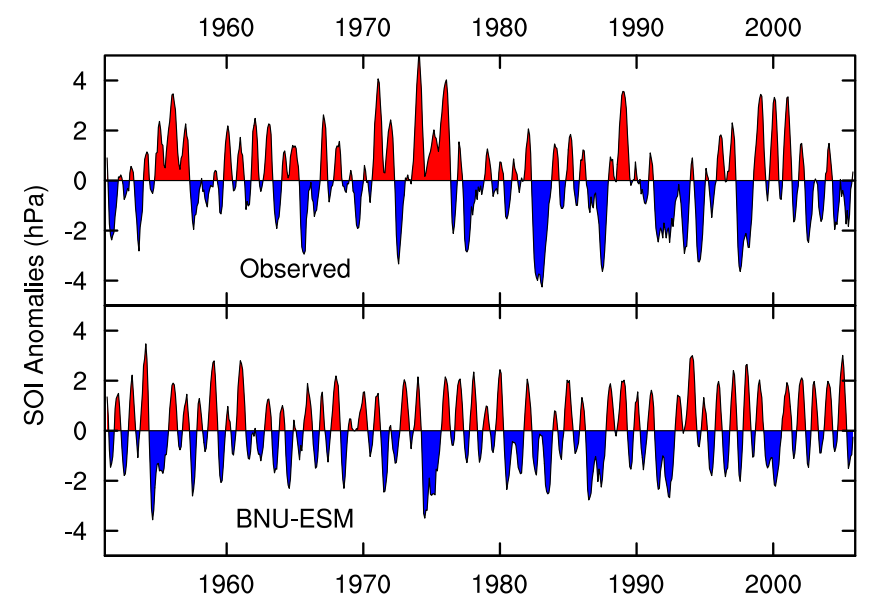

Figure 20. Time series of Southern Oscillation index (5 month running mean) from 1951 to 2005 . The observed SOI is calculated using station data from Darwin and Tahiti. Absolute, rather than normalized, time series are used here.

\subsection{Pacific Decadal Oscillation}

Another prominent structure of low-frequency climate variability in the North Pacific, with extensions to the tropical Indo-Pacific, is the Pacific Decadal Oscillation (PDO) (Mantua et al., 1997). PDO and ENSO exhibit similar spatial patterns of SST variability but with different regional emphasis (Zhang et al., 1997; Deser et al., 2007). During the positive (negative) phase of PDO, waters in the east tropical Pacific and along the North American west coast are anomalously warm (cool) while waters in the northern, western, and southern Pacific are colder (warmer) than normal. Coupled climate models can simulate some aspects of PDO, although linkages between the tropical and North Pacific are usually weaker than observed (Stoner et al., 2009; Furtado et al., 2011). Figure 21 shows the regression maps of monthly SST anomalies upon the normalized leading principal component time series of monthly SST anomalies over the North Pacific domain $\left(20-40^{\circ} \mathrm{N}\right)$. The first empirical orthogonal function (EOF) mode of BNU-ESM and HadISST observations explains 22.4 and $25.8 \%$ variance respectively. BNU-ESM exhibits generally realistic PDO spatial patterns and its connections to the tropical Pacific are of comparative strength with respect to HadISST observations, but with a narrower meridional extent in the tropical Pacific region. The maximum amplitude of the negative SST anomalies in the North Pacific shifts a little too far west, to the east of Japan, rather than in the central basin. Figure 22 shows time series of the normalized first EOF mode of SST anomalies of BNU-ESM and HadISST observations over the North Pacific domain. It is evident that both patterns show prominent decadal variability. 


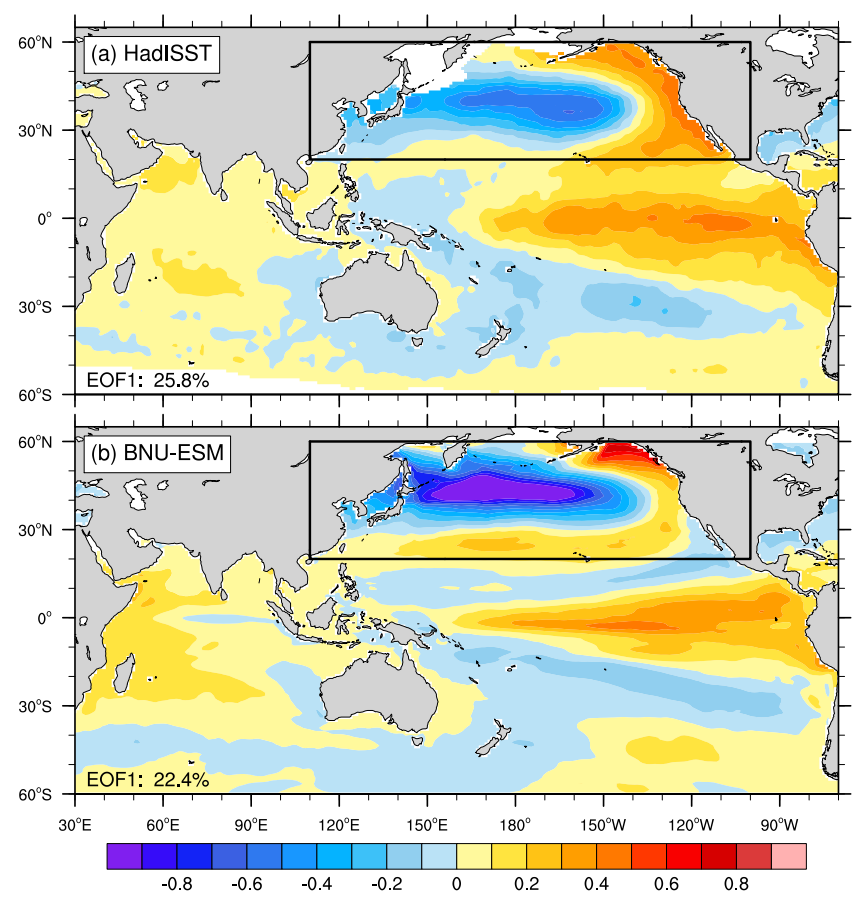

Figure 21. Leading EOF of monthly SST anomalies for the North Pacific domain (outlined by the box) for HadISST and the BNUESM historical run over the period 1900-2005. The results are shown as SST anomaly regressions upon the normalized principal component time series $\left({ }^{\circ} \mathrm{C}\right.$ per standard deviation). The numbers at the bottom left corner of each panel denote the percentage of variance explained by the leading EOF.

\section{Terrestrial carbon cycle}

\subsection{Terrestrial primary production}

Carbon flux components are hard to measure directly, presenting a challenge in evaluating the model performance. Global products for land gross primary production (GPP) and net primary production (NPP) exist but are model-based and have large uncertainties (Anav et al., 2013; Ito, 2011). Figure 23 shows regional averages of monthly land gross primary production (GPP) for BNU-ESM compared with FLUXNET-MTE estimates (Jung et al., 2011). BNU-ESM replicates the annual cycle of GPP in arctic, mid-latitudes, and tropical regions, but the model has a tendency for underestimation during boreal summer, especially over Alaska, the eastern USA, and Europe. Differences between the estimates from our model and those from FLUXNET-MTE may be caused both by differences in the near surface climatology and land cover characteristics, as BNU-ESM dynamically simulates vegetation characteristics as a function of climate and atmospheric $\mathrm{CO}_{2}$ concentration. In Alaska, the model simulates more $\mathrm{C}_{3}$ arctic grass and less boreal shrub compared with the observed International GeosphereBiosphere Programme (IGBP) vegetation distribution (not

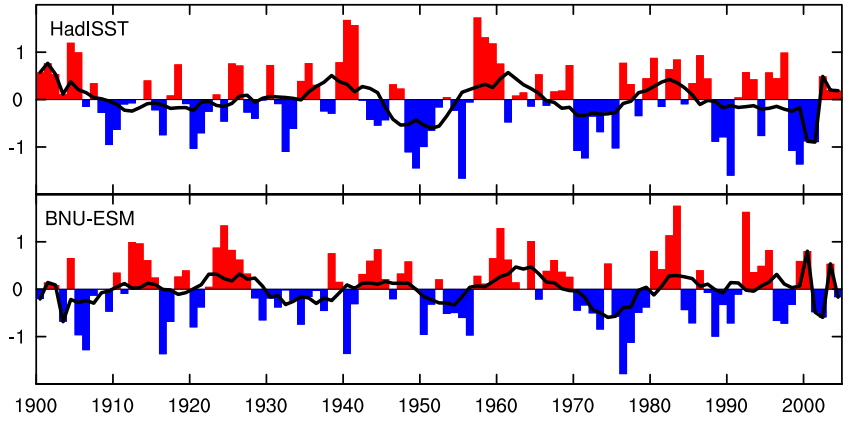

Figure 22. Time series of the normalized leading EOF mode of SST anomalies in the North Pacific domain (as Fig. 21) over the period 1900-2005 for HadISST and BNU-ESM. The solid black lines show decadal variations after 10 year running average.

shown). While in Europe, although the model simulates more broadleaf deciduous temperate tree cover and less grassland, the biased high temperature and low precipitation during boreal summer suppress GPP significantly. In the Amazon, the model simulates a reasonable vegetation distribution of broadleaf and evergreen tropical trees, but the wet season precipitation suffers a dry bias until August (Fig. 7), and the model systematically underestimates GPP. The interannual variability of the GPP estimated by the model is larger than the observational estimates from FLUXNET-MTE and this may be connected with the stronger interannual variability of the physical fields.

The global terrestrial GPP simulated in the BNU-ESM is $106.3 \mathrm{PgC} \mathrm{yr}^{-1}$ over the period 1986-2005. Various studies estimated the global terrestrial GPP to be about $120 \pm 6 \mathrm{Pg} \mathrm{C} \mathrm{yr}^{-1}$ over similar periods (Sabine et al., 2004; Beer et al., 2010; Jung et al., 2011). However, these are well below the range of $150-175 \mathrm{Pg} \mathrm{C} \mathrm{yr}^{-1}$ from recent observational estimates (Welp et al., 2011). The global simulated NPP over the period 1986-2005 is $49 \mathrm{PgC} \mathrm{yr}^{-1}$, which is consistent with the range of $42-70{\mathrm{PgC} \mathrm{yr}^{-1}}$ from earlier studies (Schimel et al., 2001; Gruber et al., 2004; Zhao et al., 2005; Ito, 2011). Net biosphere production (NBP) simulated in the model for the 1990s and 2000-2005 are 1.6 and $1.4 \mathrm{Pg} \mathrm{Cyr}^{-1}$, which is also consistent with estimates of $1.5 \pm 0.8$ and $1.1 \pm 0.8 \mathrm{PgC}^{-1}$, respectively reported by Ciais et al. (2013).

\subsection{Soil organic carbon}

Soil organic carbon is a large component of the carbon cycle that can participate in climate change feedbacks, particularly on decadal and centennial timescales (ToddBrown et al., 2013). The amount of soil organic carbon simulated by models is strongly dependent on their design, especially the number of soil-carbon pools, turnover rate of decomposition and their response to soil moisture and temperature change. Figure $24 \mathrm{a}, \mathrm{b}$ show the 
distribution of global soil organic carbon content, including litter, from BNU-ESM compared with the most recent high-resolution observation-based Harmonized World Soil Database (HWSD; FAO/IIASA/ISRIC/ISSCAS/JRC, 2012). The HWSD data provides soil-carbon estimates for topsoil $(0-30 \mathrm{~cm})$ and subsoil $(30-100 \mathrm{~cm})$ at 30 arc-second resolution. Overall, the ecosystem carbon content follows the precipitation and temperature distribution (Figs. 8 and 9). The BNU-ESM model can capture the large store of soil organic carbon in the boreal and tundra regions of Eurasia and North America, and the small storage in tropical and extra-tropical regions (Fig. 24b). The model underestimates soil-carbon density in the upper $1 \mathrm{~m}$ globally compared with the HWSD (Fig. 24a), especially in boreal regions. Soil carbon is overestimated in the model on the Tibetan plateau, because the coarse horizontal resolution does not correctly represent the rugged terrain and overestimates vegetation cover.

The total simulated soil organic carbon, including litter, is $700 \mathrm{PgC}$ for the period $1986-2005$, is well below the $1260 \mathrm{PgC}$ (with a $95 \%$ confidence interval of 890-1660 Pg C) estimated from HWSD data (Todd-Brown et al., 2013), and $1502 \mathrm{PgC}$ estimated by Jobbágy and Jackson (2000) for the upper $1 \mathrm{~m}$ of soil. However, there is still considerable uncertainty for those observation-based estimates because of limited numbers of soil profiles with organic carbon analyses (Tarnocai et al., 2009). In addition, the soil-carbon sub-model of BNU-ESM is not yet designed to simulate the large carbon accumulations in organic peat soils, or the stocks and dynamics of organic matter in permafrost, a common failure of many CMIP5 models. It is thus to be expected that simulations without these processes underestimate the global soil organic carbon stock. Especially, the temperature sensitivity of soil-carbon decomposition is described by the $Q_{10}$ equation (Lloyd and Taylor, 1994) in BNU-ESM, and the environmental controls of moisture and temperature are diagnosed at $0.25 \mathrm{~m}$ depth. In Fig. 24c, the zonally averaged soil-carbon density from BNU-ESM is compared with those from HWSD and IGBP-DIS for upper $0.3 \mathrm{~m}$ and upper $1.0 \mathrm{~m}$ depth ranges. The model simulates substantially less soil carbon than those from the HWSD and IGBP-DIS for the upper $1.0 \mathrm{~m}$, but agrees much better with upper $0.3 \mathrm{~m}$ soil-carbon density estimates on magnitude and latitudinal gradients.

\section{Summary and discussion}

In this study, the BNU-ESM is described and results for the CMIP5 pre-industrial and historical simulations are evaluated in terms of climatology and climate variability. The climatological annual cycles of surface-air temperature and precipitation generally agree with observations, but with the annual temperature underestimated and the annual precipitation overestimated over global land areas (excluding Antarctica). The sea ice extent of both polar regions agrees better
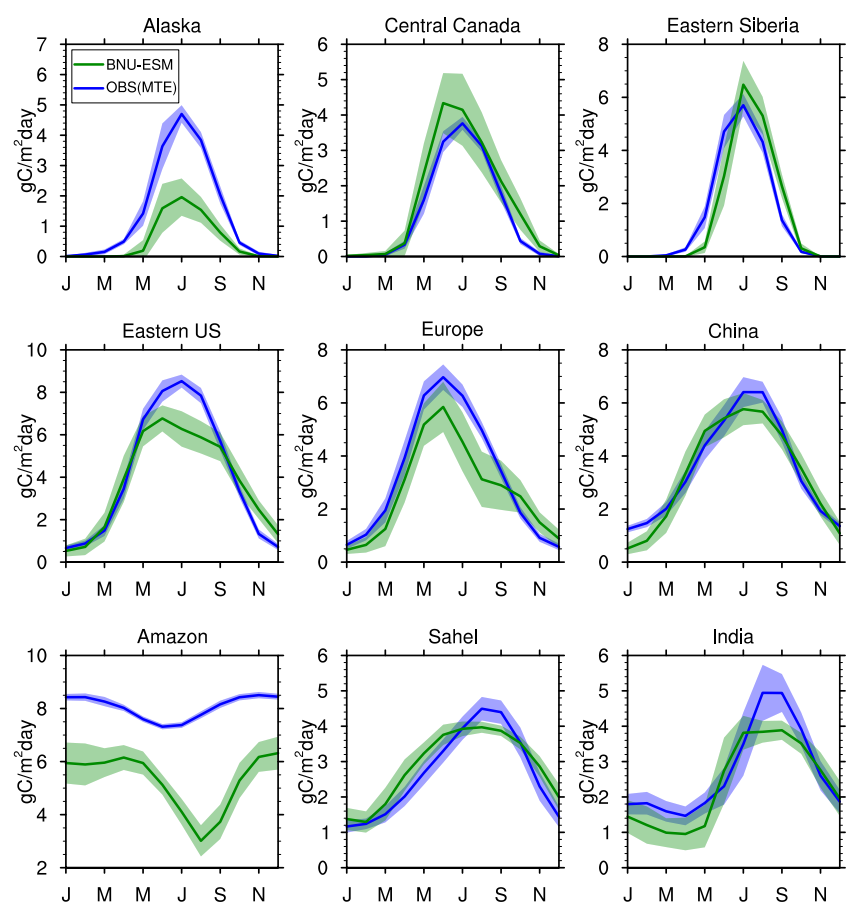

Figure 23. As for Fig. 6, but for GPP for the period 1986-2005. The observations (MTE) are from FLUXNET-MTE estimates (Jung et al., 2011).

with the observations in summer seasons than in winter seasons, and the model has a tendency to have excessive ice extent during winter seasons. The global and Atlantic ocean meridional overturning circulation patterns are similar to those observed. With respect to climate variability, BNUESM captures some features of tropical intraseasonal oscillation such as the quadrature relationship between precipitation and zonal wind in the northward propagation direction. The MJO signal in large-scale circulation (U850) is not as well simulated as it is in convection (precipitation), but the northward and eastward propagating motions are both weaker than observed. The annual cycle patterns of tropical equatorial Pacific SST, the periods of ENSO, and the leading EOF mode of PDO in the historical simulation are reasonably well simulated. As BNU-ESM has similarities and some heritage in common with CCSM4, in particular for the atmosphere, land and sea ice components, many characteristics in BNU-ESM are probably shared by CCSM4, such as some notable surface climate biases over land (Lawrence et al., 2012) and the dipole precipitation bias in the Indian Ocean.

BNU-ESM has significant biases that need to be improved, such as the tropical precipitation bias over ocean related to the double ITCZ that has long been a problem among many climate models (Lin, 2007). Note that BNU-ESM uses the revised Zhang-McFarlane scheme on deep convection (Zhang, 2002; Zhang and $\mathrm{Mu}, 2005 \mathrm{a}$ ), and CCSM4 also uses a revised Zhang-McFarlane scheme but with different emphasis 

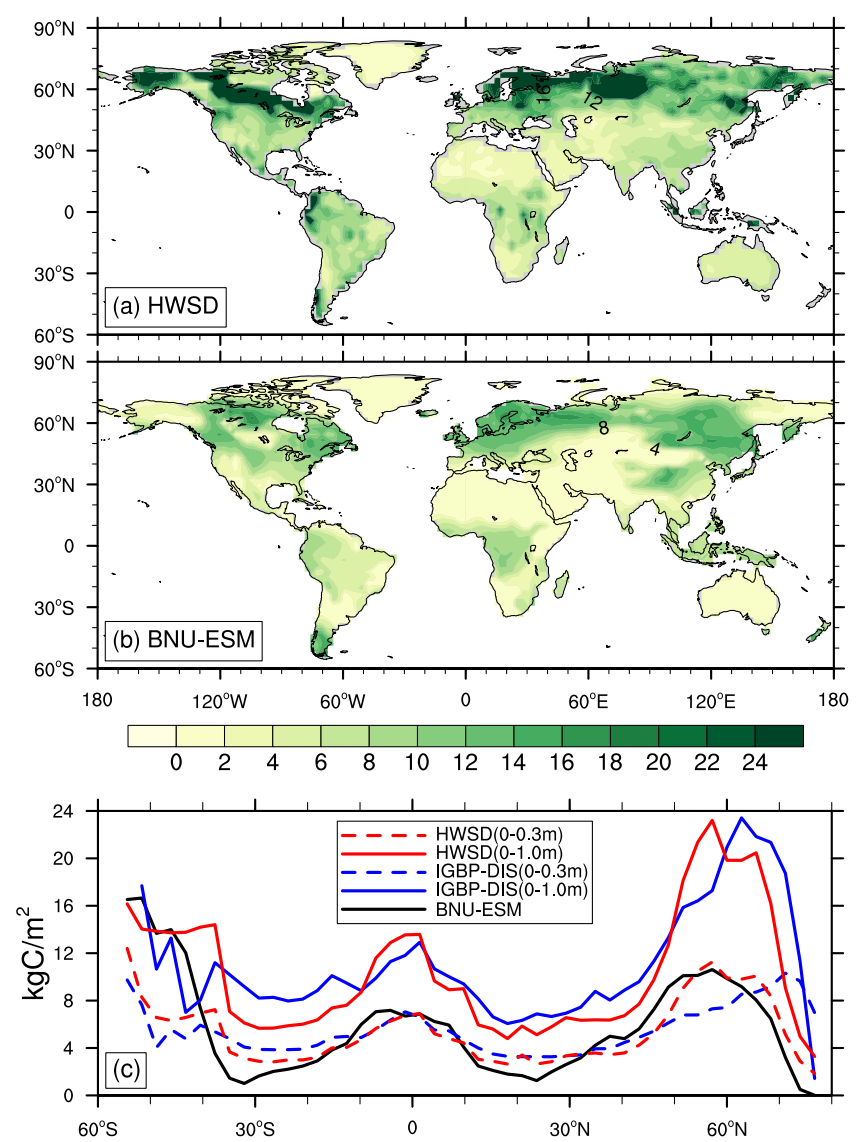

Figure 24. Soil-carbon density in the top $1 \mathrm{~m}$ depth from the HWSD (a) and BNU-ESM (b), and zonal average soil-carbon density of BNU-ESM compared with that of upper $0.3 \mathrm{~m}$ and upper $1 \mathrm{~m}$ soil from HWSD, IGBP-DIS data sets.

(Richter and Rasch, 2008; Neale et al., 2008). It turns out that neither of them eliminates the double ITCZ problem (Gent et al., 2011), so further parameterization improvements are certainly required. Land surface-air temperature simulated for the last few decades of the 20th century exhibit a mean bias greater than $2{ }^{\circ} \mathrm{C}$ over significant regions compared with observations, which also shows room for further improvements. Another related discrepancy is that modeled temperatures increase significantly during the last few years of the historical simulation relative to observations (not shown). This is very likely related to the lack of indirect aerosol effects in the atmospheric component (e.g., Gent et al., 2011), and we note that NorESM, which is also based on CCSM4, but which includes indirect of aerosol effects, does not exhibit similar problems (Bentsen et al., 2013).

The positive SST biases prevailing at major coastal upwelling regions are clearly related with the relatively coarse horizontal resolution used by the atmospheric component. According to Gent et al. (2010), the most important factor for SST improvements in CCSM3.5 is the finer resolution and better representation of topography, which produces stronger upwelling and favorable winds right along the model coasts rather than being located somewhat offshore. The cold biases in mean SST along the equator in the Pacific Ocean have several causes. One is the stronger easterly winds on the equator which result in stronger equatorial upwelling; another may be weaker activity of tropical instability waves in the ocean. The ocean component MOM4p1 uses the horizontal anisotropic friction scheme from Large et al. (2001), which induces more frictional dissipation and prohibits vigorous tropical instability wave activity (Wittenberg et al., 2006). Stronger activity of tropical instability waves could prevent the cold tongue water from cooling down by mixing with the warm off-equatorial water (Jochum and Murtugudde, 2006; Menkes et al., 2006; Seo et al., 2006; Zhang and Busalacchi, 2008). The negative SST bias in the southern ocean and excessive sea ice extent in the Antarctic suggest a need to correct the wind stress field to ensure sufficient southern ocean heat transport and proper ocean gyre boundaries.

The strength and frequency of ESNO variability in BNUESM highlights potential improvements. The model has a robust ENSO with an irregular oscillation between 2 and 5 years and a peak at about 3.5 years, whereas the HadISST observations show an oscillation between 3 and 7 years. The seasonal phase locking feature of ENSO is well captured in the model, although the standard deviation of Niño3.4 SST anomalies from the historical simulation is significantly large than in the observations. The causes of biases in ENSO occurrence and amplitude in BNU-ESM may involve many different physical processes and feedbacks. Because of the dominant role of the atmospheric component in setting ENSO characteristics (Schneider, 2002; Guilyardi et al., 2004; Kim et al., 2008; Neale et al., 2008; Wu and Kirtman, 2007; Sun et al., 2009), previous studies have diagnosed the dynamical Bjerknes feedback (Bjerknes, 1969; Neelin and Djikstra, 1995) and the heat flux feedback (Waliser et al., 1994; Jin et al., 2006) during ENSO. Bellenger et al. (2013) found that BNU-ESM underestimates both the positive Bjerknes and the negative heat flux feedbacks by about 45 and $50 \%$ respectively, which could be the major causes of the ENSO biases in the model. This also raises the importance of further improvements on the deep convection parameterization scheme, as the representation of deep convection is central in defining both the dynamical and the heat flux atmospheric feedbacks (Guilyardi et al., 2009). Another possible cause for the excessive ENSO amplitude is the lack of a sufficient surface heat flux damping of SST anomalies in the model, as weaker heat flux damping tends to destabilize and amplify ENSO (Wittenberg, 2002; Wittenberg et al., 2006). Further studies on these topics are warranted.

Despite the drawbacks of the model in simulating some details of the climate system, BNU-ESM has proven to be a useful modelling tool, and is being actively used by many researchers in prognostic simulations for both anthropogenic and geoengineering forcing scenarios. The BNU-ESM represents an addition to the diversity of earth system simulators, 
and currently is evolving in many respects. As global biogeochemical cycles are recognized as being evermore significant in mediating global climate change, improvements of BNUESM are underway in the terrestrial and marine biogeochemistry schemes. On terrestrial biogeochemistry, the LPJ-DyN based carbon-nitrogen interaction scheme (Xu and Prentice, 2008) will be evaluated and activated in the future. The soilcarbon scheme will be further improved to simulate the large carbon accumulations in organic peat soils, the stocks and dynamics of organic matter in permafrost. A dynamic marine ecosystem scheme will replace the current iBGC module, the new marine ecosystem scheme has improved parameterizations of dissolved organic materials and detritus (Wang et al., 2008), a phytoplankton dynamic module that produces a variable of carbon to chlorophyll ratio (Wang et al., 2009a), and refined nitrogen regeneration pathways (Wang et al., 2009b). Additionally, a three-dimensional canopy radiative transfer model (Yuan et al., 2014) will be adopted to replace the traditional one-dimensional two-stream approximation scheme in the land component to calculate terrestrial canopy radiation more realistically. The spatial resolution of the BNU-ESM will be increased to better the simulation of surface physical climate, especially for the atmospheric and land components. Currently a $0.9^{\circ} \times 1.25^{\circ}$ resolution land and atmosphere components adapted from the finite-volume dynamic core in CAM is being tested. We also note that CAM5 has made significant progress, such as correcting well-known cloud biases from CAM3.5 (Kay et al., 2012). Further discussions of how to incorporate these developments from CAM5 into BNU-ESM are underway.

\section{Code availability}

Please contact Duoying Ji (E-mail: duoyingji@bnu.edu.cn) to obtain the source code of BNU-ESM.

Acknowledgements. We thank four anonymous reviewers for their constructive suggestions. This research was sponsored by the National Key Program for Global Change Research of China Grant 2010CB950500, the National Natural Science Foundation of China Grant 40905047, 41305083. We acknowledge the World Climate Research Programme's Working Group on Coupled Modelling, which is responsible for CMIP; the Center of Information and Network Technology at Beijing Normal University for assistance in publishing the CMIP5 data set. ERA-Interim data used in this study is provided from the European Centre for Medium-Range Weather Forecasts (ECMWF). JRA-55 data used in this study is provided from the Japanese 55-year Reanalysis (JRA-55) project carried out by the Japan Meteorological Agency (JMA).

Edited by: M.-H. Lo

\section{References}

Adler, R. F., Huffman, G. J., Chang, A., Ferraro, R., Xie, P., Janowiak, J., Rudolf, B., Schneider, U., Curtis, S., Bolvin, D., Gruber, A., Susskind, J., and Arkin, P.: The Version 2 Global Precipitation Climatology Project (GPCP) Monthly Precipitation Analysis (1979-Present), J. Hydrometeor., 4, 1147-1167, 2003.

Ammann, C. M., Meehl, G. A., Washington, W. M., and Zender, C.: A monthly and latitudinally varying volcanic forcing dataset in simulations of 20th century climate, Geophys. Res. Lett., 30, 1657, doi:10.1029/2003GL016875, 2003.

Anav, A., Friedlingstein, P., Kidston, M., Bopp, L., Ciais, P., Cox, P., Jones, C., Jung, M., Myneni, R., and Zhu, Z.: Evaluating the Land and Ocean Components of the Global Carbon Cycle in the CMIP5 Earth System Models, J. Climate, 26, 6801-6843, doi:10.1175/JCLI-D-12-00417.1, 2013.

Annamalai, H. and Sperber, K. R.: Regional heat sources and the active and break phases of boreal summer intraseasonal (30-50 day) variability, J. Atmos. Sci., 62, 2726-2748, doi:10.1175/JAS3504.1, 2005.

Barkstrom, B. R.: The earth radiation budget experiment, Bull. Am. Meteor. Soc., 65, 1170-1185, 1984.

Beer, C., Reichstein, M., Tomelleri, E., Ciais, P., Jung, M., Carvalhais, N., Rödenbeck, C., Arain, M. A., Baldocchi, D., Bonan, G. B., Bondeau, A., Cescatti, A., Lasslop, G., Lindroth, A., Lomas, M., Luyssaert, S., Margolis, H., Oleson, K. W., Roupsard, O., Veenendaal, E., Viovy, N., Williams, C., Woodward, F. I., and Papale, D.: Terrestrial gross carbon dioxide uptake: Global distribution and covariation with climate, Science, 329, 834-838, 2010.

Bellenger, H., Guilyardi, E., Leloup, J., Lengaigne, M., and Vialard, J.: ENSO representation in climate models: From CMIP3 to CMIP5, Clim. Dynam., 42, 1999-2018, doi:10.1007/s00382013-1783-z, 2013.

Bentsen, M., Bethke, I., Debernard, J. B., Iversen, T., Kirkevåg, A., Seland, Ø., Drange, H., Roelandt, C., Seierstad, I. A., Hoose, C., and Kristjánsson, J. E.: The Norwegian Earth System Model, NorESM1-M - Part 1: Description and basic evaluation of the physical climate, Geosci. Model Dev., 6, 687-720, doi:10.5194/gmd-6-687-2013, 2013.

Bjerknes, J.: Atmospheric teleconnections from the equatorial Pacific, Mon. Wea. Rev., 97, 163-172, 1969.

Bonan, G. B.: A land surface model (LSM version 1.0) for ecological, hydrological, and atmospheric studies: Technical description and user's guide, NCAR Technical Note NCAR/TN-417+STR, National Center for Atmospheric Research, Boulder, CO, 1996.

Bonan, G. B.: The land surface climatology of the NCAR Land Surface Model coupled to the NCAR Community Climate Model, J. Climate, 11, 1307-1326, 1998.

Bonan, G. B., Lawrence, P. J., Oleson, K. W., Levis, S., Jung, M., Reichstein, M., Lawrence, D. M., and Swenson, S. C.: Improving canopy processes in the Community Land Model version 4 (CLM4) using global flux fields empirically inferred from FLUXNET data, J. Geophys. Res., 116, G02014, doi:10.1029/2010JG001593, 2011.

Bracegirdle, T. J., Shuckburgh, E., Sallee, J.-B., Wang, Z., Meijers, A. J. S., Bruneau, N., Phillips, T., and Wilcox, L. J.: Assessment of surface winds over the Atlantic, Indian, and Pacific Ocean sectors of the Southern Ocean in CMIP5 models: histor- 
ical bias, forcing response, and state dependence, J. Geophys. Res.-Atmos., 118, 547-562, doi:10.1002/jgrd.50153, 2013.

Chang, C.-P., Zhang, Y., and Li, T.: Interannual and Interdecadal Variations of the East Asian Summer Monsoon and Tropical Pacific SSTs, Part I: Roles of the Subtropical Ridge, J. Climate, 13, 4310-4325, doi:10.1175/15200442(2000)013<4310:IAIVOT>2.0.CO;2, 2000.

Charlton-Perez, A. J., Baldwin, M. P., Birner, T., Black, R. X, Butler, A. H., Calvo, N., Davis, N. A., Gerber, E. P., Gillett, N., Hardiman, S., Kim, J., Krüger, K., Lee, Y.-Y., Manzini, E., McDaniel, B. A., Polvani, L., Reichler, T., Shaw, T. A., Sigmond, M., Son, S.-W., Toohey, M., Wilcox, L., Yoden, S., Christiansen, B., Lott, F., Shindell, D., Yukimoto, S. and Watanabe, S.: On the lack of stratospheric dynamical variability in low-top versions of the CMIP5 models, J. Geophys. Res.-Atmos., 118, 2494-2505, doi:10.1002/jgrd.50125, 2013.

Chen, L., Yu, Y., and Sun, D.-Z.: Cloud and Water Vapor Feedbacks to the El Niño Warming: Are They Still Biased in CMIP5 Models?, J. Climate, 26, 4947-4961, doi:10.1175/JCLI-D-1200575.1, 2013.

Ciais, P., Sabine, C., Bala, G., Bopp, L., Brovkin, V., Canadell, J., Chhabra, A., DeFries, R., Galloway, J., Heimann, M., Jones, C., Quéré, C. L., Myneni, R. B., Piao, S., and Thornton, P.: Carbon and Other Biogeochemical Cycles, in: Climate Change 2013: The Physical Science Basis. Contribution of Working Group I to the Fifth Assessment Report of the Intergovernmental Panel on Climate Change, Cambridge University Press, Cambridge, United Kingdom and New York, NY, USA, 2013.

Comiso, J.: Bootstrap Sea Ice Concentrations from Nimbus-7 SMMR and DMSP SSM/I-SSMIS, Version 2, updated 2012. Boulder, Colorado USA: NASA DAAC at the National Snow and Ice Data Center, available at: http://nsidc.org/data/docs/daac/ nsidc0079_bootstrap_seaice.gd.html (last access: October 2013), 1999.

Cunningham, S., Alderson, S., King, B., and Brandon, M.: Transport and variability of the Antarctic Circumpolar Current in Drake Passage, J. Geophys. Res., 108, 8084, doi:10.1029/2001JC001147, 2003.

Dai, Y. and Zeng, Q.: A land surface model (IAP94) for climate studies. Part I: formulation and validation in off-line experiments, Adv. Atmos. Sci., 14, 433-460, 1997.

Dai, Y., Zeng, X., Dickinson, R. E., and Coauthors: Common Land Model: Technical documentation and user's guide, available at: http://globalchange.bnu.edu.cn/download/doc/CoLM/ CoLM_doc.tar.gz (last access: January 2014), 2001.

Dai, Y., Zeng, X., Dickinson, R. E., Baker, I., Bonan, G. B., Bosilovich, M. G., Denning, A. S., Dirmeyer, P. A., Houser, P. R., Niu, G., Oleson, K. W., Schlosser, C. A., and Yang, Z.-L.: The Common Land Model (CLM), Bull. Am. Meteor. Soc., 84, 1013-1023, doi:10.1175/BAMS-84-8-1013, 2003.

Dai, Y., Dickinson, R. E., and Wang, Y.-P.: A two-big-leaf model for canopy temperature, photosynthesis, and stomatal conductance, J. Climate, 17, 2281-2299, doi:10.1175/15200442(2004)017<2281:ATMFCT>2.0.CO;2, 2004.

Dee, D. P., Uppala, S. M., Simmons, A. J., Berrisford, P., Poli, P., Kobayashi, S., Andrae, U., Balmaseda, M. A., Balsamo, G., Bauer, P., Bechtold, P., Beljaars, A. C. M., van de Berg, L., Bidlot, J., Bormann, N., Delsol, C., Dragani, R., Fuentes, M., Geer, A. J., Haimberger, L., Healy, S. B., Hersbach, H., Hólm, E. V.,
Isaksen, L., Kållberg, P., Köhler, M., Matricardi, M., McNally, A. P., Monge-Sanz, B. M., Morcrette, J.-J., Park, B.-K., Peubey, C., de Rosnay, P., Tavolato, C., Thépaut, J.-N., and Vitart, F.: The ERA-Interim reanalysis: configuration and performance of the data assimilation system, Q. J. Roy. Meteorol. Soc., 137, 553597, doi:10.1002/qj.828, 2011.

Deser, C., Tomas, R. A., and Peng, S.: The transient atmospheric circulation response to North Atlantic SST and sea ice anomalies, J. Climate, 20, 4751-4767, 2007.

Dickinson, R. E., Henderson-Sellers, A., and Kennedy, P. J.: Biosphere-Atmosphere Transfer Scheme (BATS) version 1e as coupled to the NCAR Community Climate Model, NCAR Technical Note NCAR/TN-387+STR, National Center for Atmospheric Research, Boulder, CO, 1993.

Ebita, A., Kobayashi, S., Ota, Y., Moriya, M., Kumabe, R., Onogi, K., Harada, Y., Yasui, S., Miyaoka, K., Takahashi, K., Kamahori, H., Kobayashi, C., Endo, H., Soma, M., Oikawa, Y., and Ishimizu, T.: The Japanese 55-year Reanalysis "JRA-55": An Interim Report, SOLA, 7, 149-152, doi:10.2151/sola.2011-038, 2011.

FAO/IIASA/ISRIC/ISSCAS/JRC: Harmonized World Soil Database (version 1.2), FAO, Rome, Italy and IIASA, Laxenburg, Austria, 2012.

Fetterer, F., Knowles, K., Meier, W., and Savoie, M.: Sea Ice Index, Boulder, Colorado USA: National Snow and Ice Data Center, Digital media, available at: http://nsidc.org/data/docs/noaa/ g02135_seaice_index/ (last access: October 2013), 2002, updated 2009.

Fettweis, X., Hanna, E., Lang, C., Belleflamme, A., Erpicum, M., and Gallee, H.: Brief communication "Important role of the midtropospheric atmospheric circulation in the recent surface melt increase over the Greenland ice sheet", The Cryosphere, 7, 241 248, doi:10.5194/tc-7-241-2013, 2013.

Flato, G., Marotzke, J., Abiodun, B., Braconnot, P., Chou, S. C., Collins, W., Cox, P., Driouech, F., Emori, S., Eyring, V., Forest, C., Gleckler, P., Guilyardi, E., Jakob, C., Kattsov, V., Reason, C., and Rummukainen, M.: Evaluation of Climate Models, in: Climate Change 2013: The Physical Science Basis, Contribution of Working Group I to the Fifth Assessment Report of the Intergovernmental Panel on Climate Change, edited by: Stocker, T. F., Qin, D., Plattner, G.-K., Tignor, M., Allen, S. K., Boschung, J., Nauels, A., Xia, Y., Bex, V., and Midgley, P. M., Cambridge University Press, Cambridge, United Kingdom and New York, NY, USA, 2013.

Furtado, J. C., Lorenzo, E. D., Schneider, N., and Bond, N. A.: North Pacific Decadal Variability and Climate Change in the IPCC AR4 Models, J. Climate, 24, 3049-3067, doi:10.1175/2010JCLI3584.1, 2011.

Gent, P. R., Yeager, S. G., Neale, R. B., Levis, S., and Bailey, D. A.: Improvements in a half degree atmosphere/land version of the CCSM, Clim. Dynam., 34, 819-833, doi:10.1007/s00382-0090614-8, 2010.

Gent, P. R., Danabasoglu, G., Donner, L. J., Holland, M. M., Hunke, E. C., Jayne, S. R., Lawrence, D. M., Neale, R. B., Rasch, P. J., Vertenstein, M., Worley, P. H., Yang, Z.-L., and Zhang, M: The Community Climate System Model Version 4, J. Climate, 24, 4973-4991, doi:10.1175/2011JCLI4083.1, 2011.

Ghil, M., Allen, M. R., Dettinger, M. D., Ide, K., Kondrashov, D., Mann, M. E., Robertson, A. W., Saunders, A., Tian, Y., Varadi, F., 
and Yiou, P.: Advanced spectral methods for climatic time series, Rev. Geophys., 40, 1003, doi:10.1029/2000RG000092, 2002.

Gillett, N. P. and Fyfe, J. C.: Annular mode changes in the CMIP5 simulations, Geophys. Res. Lett., 40, 1189-1193, doi:10.1002/grl.50249, 2013.

Gleckler, P. J., Taylor, K. E., and Doutriaux, C.: Performance metrics for climate models, J. Geophys. Res., 113, D06104, doi:10.1029/2007JD008972, 2008.

Griffies, S. M.: Elements of MOM4p1, GFDL Ocean Group Technical Report No. 6, NOAA/Geophysical Fluid Dynamics Laboratory, 444 pp., 2010.

Gruber, N., Friedlingstein, P., Field, C. B., Valentini, R., Heimann, M., Richey, J. E., Lankao, P. R., Schulze, E.-D., and Chen, C.T. A.: The vulnerability of the carbon cycle in the 21 st century: An assessment of carbon-climate-human interactions, in: The Global Carbon Cycle: Integrating Humans, Climate, and the Natural World, edited by: Field, C. B. and Raupach, M. R., Island Press, Washington, Covelo, London, 2004.

Guilyardi, E., Gualdi, S., Slingo, J., Navarra, A., Delecluse, P., Cole, J., Madec, G., Roberts, M., Latif, M., and Terray, L.: Representing El Niño in Coupled Ocean-Atmosphere GCMs: The Dominant Role of the Atmospheric Component, J. Climate, 17, 46234629, doi:10.1175/JCLI-3260.1, 2004.

Guilyardi, E., Braconnot, P., Jin, F.-F., Kim, S. T., Kolasinski, M., Li, T., and Musat, I.: Atmosphere Feedbacks during ENSO in a Coupled GCM with a Modified Atmospheric Convection Scheme, J. Climate, 22, 5698-5718, doi:10.1175/2009JCLI2815.1, 2009.

Gupta, A. S., Santoso, A., Taschetto, A. S., Ummenhofer, C. C., Trevena, J., and England, M. H.: Projected changes to the southern hemisphere ocean and sea ice in the IPCC AR4 climate models, J. Climate, 22, 3047-3078, doi:10.1175/2008JCLI2827.1, 2009.

Harris, I., Jones, P. D., Osborn, T. J., and Lister, D. H.: Updated high-resolution grids of monthly climatic observations, Int. J. Climatol., 34, 623-642, doi:10.1002/joc.3711, 2014.

Huffman, G. J., Adler, R. F., Morrissey, M. M., Curtis, S., Joyce, R., McGavock, B., and Susskind, J.: Global precipitation at onedegree daily resolution from multi-satellite observations, J. Hydrometeor., 2, 36-50, 2001.

Hung, M.-P., Lin, J.-L., Wang, W., Kim, D., Shinoda, T., and Weaver, S. J.: MJO and Convectively Coupled Equatorial Waves Simulated by CMIP5 Climate Models, J. Climate, 26, 61856214, doi:10.1175/JCLI-D-12-00541.1, 2013.

Hunke, E. C. and Lipscomb, W. H.: CICE: The Los Alamos sea ice model user's manual, version 4.1. Los Alamos National Laboratory Tech. Rep. LA-CC-06-012, 76 pp., 2010.

IGBP-DIS: Global Soil Data Task Group. Global Gridded Surfaces of Selected Soil Characteristics, Global Gridded Surfaces of Selected Soil Characteristics (International Geosphere-Biosphere Programme - Data and Information System), Data set, available at: http://daac.ornl.gov/SOILS/guides/igbp-surfaces.html (last access: May 2014) from Oak Ridge National Laboratory Distributed Active Archive Center, Oak Ridge, Tennessee, USA, doi:10.3334/ORNLDAAC/569, 2000.

Ito, A.: A historical meta-analysis of global terrestrial net primary productivity: are estimates converging?, Glob. Change Biol., 17, 3161-3175, doi:10.1111/j.1365-2486.2011.02450.x, 2011.
Ji, D. and Dai, Y.: The Common Land Model (CoLM) Technical Guide, available at: http://globalchange.bnu.edu.cn/download/ doc/CoLM/CoLM_Technical_Guide.pdf (last access: January 2014), 2010.

Jin, F.-F., Kim, S. T., and Bejarano, L.: A coupled-stability index for ENSO, Geophys. Res. Lett., 33, L23708, doi:10.1029/2006GL027221, 2006.

Jobbágy, E. G. and Jackson, R. B.: The vertical distribution of soil organic carbon and its relation to climate and vegetation, Ecol. Appl., 10, 423-436, doi:10.1890/10510761(2000)010[0423:TVDOSO]2.0.CO;2, 2000.

Jochum, M. and Murtugudde, R.: Temperature advection by tropical instability waves, J. Phys. Oceanogr., 36, 592-605, 2006.

Josey, S. A., Kent, E. C., and Taylor, P. K.: New insights into the ocean heat budget closure problem from analysis of the SOC airsea flux climatology, J. Climate, 12, 2856-2880, 1999.

Jung, M., Reichstein, M., Margolis, H. A., Cescatti, A., Richardson, A. D., Arain, M. A., Arneth, A., Bernhofer, C., Bonal, D., Chen, J., Gianelle, D., Gobron, N., Kiely, G., Kutsch, W., Lasslop, G., Law, B. E., Lindroth, A., Merbold, L., Montagnani, L., Moors, E. J., Papale, D., Sottocornola, M., Vaccari, F., and Williams, C.: Global patterns of land-atmosphere fluxes of carbon dioxide, latent heat, and sensible heat derived from eddy covariance, satellite, and meteorological observations, J. Geophys. Res., 116, G00J07, doi:10.1029/2010JG001566, 2011.

Kay, J. E., Hillman, B. R., Klein, S. A., Zhang, Y., Medeiros, B., Pincus, R., Gettelman, A., Eaton, B., Boyle, J., Marchand, R., and Ackerman, T. P.: Exposing Global Cloud Biases in the Community Atmosphere Model (CAM) Using Satellite Observations and Their Corresponding Instrument Simulators, J. Climate, 25, 5190-5207, doi:10.1175/JCLI-D-11-00469.1, 2012.

Kiladis, G. N. and Weickmann, K. M.: Circulation anomalies associated with tropical convection during northern winter, Mon. Weather Rev., 120, 1900-1923, 1992.

Kim, D., Kug, J.-S., Kang, I.-S., Jin, F.-F., and Wittenberg, A. T.: Tropical Pacific impacts of convective momentum transport in the SNU coupled GCM, Clim. Dynam., 31, 213-226, 2008.

Kim, D., Sperber, K., Stern, W., Waliser, D., Kang, I.-S., Maloney, E., Wang, W., Weickmann, K., Benedict, J., Khairoutdinov, M., Lee, M.-I., Neale, R., Suarez, M., Thayer-Calder, K., and Zhang, G.: Application of MJO Simulation Diagnostics to Climate Models, J. Climate, 22, 6413-6436, doi:10.1175/2009JCLI3063.1, 2009.

Kravitz, B., Robock, A., Boucher, O., Schmidt, H., Taylor, K. E., Stenchikov, G., and Schulz, M.: The Geoengineering Model Intercomparison Project (GeoMIP), Atmos. Sci. Lett., 12, 162167, doi:10.1002/asl.316, 2011.

Krishnamurti, T. N. and Subrahmanyam, D.: The 30-50-day mode at $850 \mathrm{mb}$ during MONEX, J. Atmos. Sci., 39, 2088-2095, 1982.

Kummerow, C., Simpson, J., Thiele, O., Barnes, W., Chang, A. T. C., Stocker, E., Adler, R. F., Hou, A., Kakar, R., Wentz, F., Ashcroft, P., Kozu, T., Hong, Y., Okamoto, K., Iguchi, T., Kuroiwa, H., Im, E., Haddad, Z., Huffman, G., Ferrier, B., O1son, W. S., Zipser, E., Smith, E. A., Wilheit, T. T., North, G., Krishnamurti, T., and Nakamura, K.: The Status of the Tropical Rainfall Measuring Mission (TRMM) after Two Years in Orbit, J. Appl. Meteor., 39, 1965-1982, doi:10.1175/15200450(2001)040<1965:TSOTTR>2.0.CO;2, 2000. 
Lamarque, J.-F., Bond, T. C., Eyring, V., Granier, C., Heil, A., Klimont, Z., Lee, D., Liousse, C., Mieville, A., Owen, B., Schultz, M. G., Shindell, D., Smith, S. J., Stehfest, E., Van Aardenne, J., Cooper, O. R., Kainuma, M., Mahowald, N., McConnell, J. R., Naik, V., Riahi, K., and van Vuuren, D. P.: Historical (1850-2000) gridded anthropogenic and biomass burning emissions of reactive gases and aerosols: methodology and application, Atmos. Chem. Phys., 10, 7017-7039, doi:10.5194/acp10-7017-2010, 2010.

Large, W., McWilliams, J. C., and Doney, S. C.: Oceanic vertical mixing: A review and a model with a nonlocal boundary mixing parameterization, Rev. Geophys., 32, 363-403, 1994.

Large, W. G., Danabasoglu, G., McWilliams, J. C., Gent, P. R., and Bryan, F. O.: Equatorial circulation of a global ocean climate model with anisotropic horizontal viscosity, J. Phys. Oceanogr., 31, 518-536, 2001.

Lau, K.-M. and Chan, P. H.: Aspects of the 40-50 day oscillation during the northern summer as inferred from outgoing longwave radiation, Mon. Weather Rev., 114, 1354-1367, 1986.

Lau, W. K. M. and Waliser, D. E.: Intraseasonal variability of the atmosphere-ocean climate system, Springer, ISBN: 978-3-64213913-0, 2012.

Lawrence, D. M., Oleson, K. W., Flanner, M. G., Thornton, P. E., Swenson, S. C., Lawrence, P. J., Zeng, X., Yang, Z.-L., Levis, S., Sakaguchi, K., Bonan, G. B., and Slater, A. G.: Parameterization improvements and functional and structural advances in Version 4 of the Community Land Model, J. Adv. Model. Earth Syst., 3, M03001, doi:10.1029/2011MS000045, 2011.

Lawrence, D. M., Oleson, K. W., Flanner, M. G., Fletcher, C. G., Lawrence, P. J., Levis, S., Swenson, S. C., and Bonan, G. B.: The CCSM4 Land Simulation, 1850-2005: Assessment of Surface Climate and New Capabilities, J. Climate, 25, 2240-2260, doi:10.1175/JCLI-D-11-00103.1, 2012.

Lean, J., Rottman, G., Harder, J., and Kopp, G.: SORCE contributions to new understanding of global change and solar variability, Sol. Phys., 230, 27-53, 2005.

L'Ecuyer, T. S., Wood, N. B., Haladay, T., Stephens, G. L., and Stackhouse Jr., P. W.: Impact of clouds on atmospheric heating based on the R04 CloudSat fluxes and heating rates data set, J. Geophys. Res., 113, D00A15, doi:10.1029/2008JD009951, 2008.

Li, G. and Xie, S.-P.: Tropical Biases in CMIP5 Multimodel Ensemble: The Excessive Equatorial Pacific Cold Tongue and Double ITCZ Problems, J. Climate, 27, 1765-1780, doi:10.1175/JCLID-13-00337.1, 2014.

Li, H., Dai, A., Zhou, T., and Lu, J.: Responses of East Asian summer monsoon to historical SST and atmospheric forcing during 1950-2000, Clim. Dynam., 34, 501-514, 2010.

Lin, J.-L.: The Double-ITCZ Problem in IPCC AR4 Coupled GCMs: Ocean-Atmosphere Feedback Analysis, J. Climate, 20, 4497-4525, doi:10.1175/JCLI4272.1, 2007.

Lin, J.-L., Kiladis, G. N., Mapes, B. E., Weickmann, K. M., Sperber, K. R., Lin, W., Wheeler, M. C., Schubert, S. D., Genio, A. D., Donner, L. J., Emori, S., Gueremy, J.-F., Hourdin, F., Rasch, P. J., Roeckner, E., and Scinocca, J. F.: Tropical intraseasonal variability in 14 IPCC AR4 climate models. Part I: Convective signals, J. Climate, 19, 2665-2690, doi:10.1175/JCLI3735.1, 2006.

Liu, J., Song, M., Horton, R. M., and Hu, Y.: Reducing spread in climate model projections of a September ice- free Arctic, Proc. Natl. Acad. Sci. USA, 110, 12571-12576, doi:10.1073/pnas.1219716110, 2013.

Lloyd, J. and Taylor, J. A.: On the temperature dependence of soil respiration, Funct. Ecol., 8, 315-323, 1994.

Loeb, N. G., Wielicki, B. A., Doelling, D. R., Smith, G. L., Keyes, D. F., Kato, S., Manalo-Smith, N., and Wong, T.: Toward optimal closure of the earth's top-of-atmosphere radiation budget, J. Climate, 22, 748-766, 2009.

Losch, M., Menemenlis, D., Campin, J.-M., Heimbach, P., and Hill, C.: On the formulation of sea-ice models. Part 1: Effects of different solver implementations and parameterizations, Ocean Model., 33, 129-144, 2010.

Lumpkin, R. and Speer, K.: Global ocean meridional overturning, J. Phys. Oceanogr., 37, 2550-2562, 2007.

Ma, H.-Y., Xie, S., Klein, S. A., Williams, K. D., Boyle, J. S., Bony, S., Douville, H., Fermepin, S., Medeiros, B., Tyteca, S., Watanabe, M., and Williamson, D.: On the correspondence between mean forecast errors and climate errors in CMIP5 models, J. Climate, 27, 1781-1798, doi:10.1175/JCLI-D-13-00474.1, 2014.

Madden, R. and Julian, P.: Detection of a 40-50 day oscillation in the zonal wind in the tropical Pacific, J. Atmos. Sci., 28, 702708, 1971.

Madden, R. and Julian, P.: Description of global-scale circulation cells in the tropics with a 40-50 day period, J. Atmos. Sci., 29, 1109-1123, 1972.

Mantua, N. J., Hare, S. R., Zhang, Y., Wallace, J. M., and Francis, R. C.: A Pacific interdecadal oscillation with impacts on salmon production, Bull. Am. Meteor. Soc., 78, 1069-1079, 1997.

Matsuura, K. and Willmott, C. J.: Terrestrial air temperature: 1900-2008 gridded monthly time series, version 2.01, available at: http://climate.geog.udel.edu/ climate (last access: October 2013), 2009a.

Matsuura, K. and Willmott, C. J.: Terrestrial precipitation: 19002008 gridded monthly time series, version 2.01, available at: http: //climate.geog.udel.edu/ climate/ (last access: October 2013), 2009b.

Meijers, A. J. S., Shuckburgh, E., Bruneau, N., Sallee, J.-B., Bracegirdle, T. J., and Wang, Z.: Representation of the Antarctic Circumpolar Current in the CMIP5 climate models and future changes under warming scenarios, J. Geophys. Res., 117, C12008, doi:10.1029/2012JC008412, 2012.

Menkes, C., Vialard, J., Kennan, S. C., Boulanger, J.-P., and Madec, G. V.: A modeling study of the impact of tropical instability waves on the heat budget of the eastern equatorial Pacific, J Phys. Oceanogr., 36, 847-865, 2006.

Moore, J. C., Rinke, A., Yu, X., Ji, D., Li, Y., Alterskjær, K., Cui, X., Kristjánsson, J. E., Muri, H., Boucher, O., Huneeus, N., Kravitz, B., Robock, A., Niemeier, U., Schulz, M., Tilmes, S., Watanabe S., and Yang, S.: Arctic sea ice and atmospheric circulation under the GeoMIP G1 scenario, J. Geophys. Res., 119, 567-583, doi:10.1002/2013JD021060, 2014.

Murray, R. J.: Explicit generation of orthogonal grids for ocean models, J. Comput. Phys., 126, 251-273, 1996.

Neale, R. B., Richter, J. H., and Jochum, M.: The impact of convection on ENSO: From a delayed oscillator to a series of events, J. Climate, 21, 5904-5924, 2008.

Neale, R. B., Richter, J. H., Conley, A. J., Park, S., Lauritzen, P. H., Gettelman, A., Williamson, D. L., Rasch, P. J., Vavrus, S. J., Taylor, M. A., Collins, W. D., Zhang, M., 
and Lin, S.-J.: Description of the NCAR Community Atmosphere Model (CAM 4.0), NCAR TECHNICAL NOTE: NCAR/TN-485+STR, available at: http://www.cesm.ucar.edu/ models/ccsm4.0/cam/docs/description/cam4_desc.pdf (last access: October 2013), 2010.

Neale, R. B., Richter, J., Park, S., Lauritzen, P. H., Vavrus, S. J., Rasch, P. J., and Zhang, M.: The Mean Climate of the Community Atmosphere Model (CAM4) in Forced SST and Fully Coupled Experiments, J. Climate, 26, 5150-5168, doi:10.1175/JCLID-12-00236.1, 2013.

Neelin, J. D. and Dijkstra, H. A.: Ocean-atmosphere interaction and the tropical climatology, Part I: The dangers of flux correction, J. Climate, 8, 1325-1342, 1995.

Oleson, K. W., Lawrence, D. M., Bonan, G. B., Flanner, M. G., Kluzek, E., Lawrence, P. J., Levis, S., Swenson, S. C., Thornton, P. E., Dai, A., Decker, M., Dickinson, R. E., Feddema, J., Heald, C. L., Hoffman, F., Lamarque, J.-F., Mahowald, N., Niu, G.-Y., Qian, T., Randerson, J., Running, S., Sakaguchi, K., Slater, A., Stöckli, R., Wang, A., Yang, Z.-L., Zeng, X., and Zeng, X.: Technical description of version 4.0 of the Community Land Model, NCAR Tech. Note NCAR/TN-478+STR, available at: http://www.cesm.ucar.edu/models/cesm1.0/clm/CLM4Tech_ Note.pdf (last access: October 2013), 2010.

Orsi, A. H., Johnson, G. C., and Bullister, J. L.: Circulation, mixing, and production of Antarctic bottom water, Prog. Oceanogr., 43, 55-109, 1999.

Ramanathan, V., Cess, R. D., Harrison, E. F., Minnis, P., Barkstrom, B. R., Ahmad, E., and Hartmann, D.: Radiative forcing and climate: Results from the Earth Radiation Budget Experiment, Science, 243, 57-63, doi:10.1126/science.243.4887.57, 1989.

Raymond, D. J. and Blyth, A. M.: A stochastic mixing model for non-precipitating cumulus clouds, J. Atmos. Sci., 43, 27082718, 1986.

Raymond, D. J. and Blyth, A. M.: Extension of the stochastic mixing model to cumulonimbus clouds, J. Atmos. Sci., 49, 19681983, 1992.

Rayner, D., Hirschi, J. J.-M., Kanzow, T., Johns, W. E., Wright, P. G., Frajka-Williams, E., Bryden, H. L., Meinen, C. S., Baringer, M. O., Marotzke, J., Beal, L. M., and Cunningham, S. A.: Monitoring the Atlantic meridional overturning circulation, Deep Sea Res. Pt. II, 58, 1744-1753, 2011.

Rayner, N. A., Parker, D. E., Horton, E. B., Folland, C. K., Alexander, L. V., Rowell, D. P., Kent, E. C., and Kaplan, A.: Global analyses of sea surface temperature, sea ice, and night marine air temperature since the late nineteenth century, J. Geophys. Res., 108, 4407, doi:10.1029/2002JD002670, 2003.

Reynolds, R. W., Rayner, N. A., Smith, T. M., Stokes, D. C., and Wang, W.: An improved in situ and satellite SST analysis for climate, J. Climate, 15, 1609-1625, 2002.

Richter, J. H. and Rasch, P. J.: Effects of convective momentum transport on the atmospheric circulation in the Community Atmosphere Model, version 3, J. Climate, 21, 1487-1499, 2008.

Rienecker, M. M., Suarez, M. J., Gelaro, R., Todling, R., Bacmeister, J., Liu, E., Bosilovich, M. G., Schubert, S. D., Takacs, L., Kim, G.-K., Bloom, S., Chen, J., Collins, D., Conaty, A., da Silva A., Gu, W., Joiner, J., Koster, R. D., Lucchesi, R., Molod, A., Owens, T., Pawson, S., Pegion, P., Redder, C. R., Reichle, R., Robertson, F. R., Ruddick, A. G., Sienkiewicz, M., and Woollen, J.: MERRA: NASA's Modern-Era Retrospective Anal- ysis for Research and Applications, J. Climate, 24, 3624-3648, doi:10.1175/jcli-d-11-00015.1, 2011.

Roberts, M. J., Banks, H., Gedney, N., Gregory, J., Hill, R., Mullerworth, S., Pardaens, A., Rickard, G., Thorpe, R., and Wood, R.: Impact of an Eddy-Permitting Ocean Resolution on Control and Climate Change Simulations with a Global Coupled GCM, J. Climate, 17, 3-20, doi:10.1175/15200442(2004)017<0003:IOAEOR>2.0.CO;2, 2004.

Roehrig, R., Bouniol, D., Guichard, F., Hourdin, F., and Redelsperger, J.-L.: The Present and Future of the West African Monsoon: A Process-Oriented Assessment of CMIP5 Simulations along the AMMA Transect, J. Climate, 26, 6471-6505, doi:10.1175/JCLI-D-12-00505.1, 2013.

Rossow, W. B. and Schiffer, R. A.: Advances in understanding clouds from ISCCP, Bull. Am. Meteor. Soc., 80, 2261-2287, 1999.

Rossow, W. B. and Dueñas, E. N.: The International Satellite Cloud Climatology Project (ISCCP) Web Site: An Online Resource for Research, Bull. Am. Meteor. Soc., 85, 167-172, doi:10.1175/BAMS-85-2-167, 2004.

Sabeerali, C. T., Dandi, A. R., Dhakate, A., Salunke, K., Mahapatra, S., and Rao, S. A.: Simulation of boreal summer intraseasonal oscillations in the latest CMIP5 coupled GCMs, J. Geophys. Res.Atmos., 118, 4401-4420, doi:10.1002/jgrd.50403, 2013.

Sabine, C. L., Feely, R. A., Gruber, N., Key, R. M., Lee, K., Bullister, J. L., Wanninkhof, R., Wong, C. S., Wallace, D. W. R., Tilbrook, B., Millero, F. J., Peng, T.-H., Kozyr, A., Ono, T., and Rios, A. F.: The oceanic sink for anthropogenic $\mathrm{CO}_{2}$, Science, 305, 367-371, 2004.

Schimel, D. S., House, J. I., Hibbard, K. A., Bousquet, P., Ciais, P., Peylin, P., Braswell, B. H., Apps, M. J., Baker, D., Bondeau, A., Canadell, J., Churkina, G., Cramer, W., Denning, A. S., Field, C. B., Friedlingstein, P., Goodale, C., Heimann, M., Houghton, P. A., Melillo, J. M., Moore, B., III, Murdiyarso, D., Noble, I., Pacala, S. W., Prentice, I. C., Raupach, M. R., Rayner, P. J., Scholes, R. J., Steffen, W. L., and Wirth, C.: Recent patterns and mechanisms of carbon exchange by terrestrial ecosystems, Nature, 414, 169-172, 2001.

Schneider, E. K.: Understanding differences between the equatorial Pacific as simulated by two coupled GCMs, J. Climate, 15, 449469, 2002.

Seo, H., Jochum, M., Murtugudde, R., and Miller, A. J.: Effect of ocean mesoscale variability on the mean state of tropical Atlantic climate, Geophys. Res. Lett., 33, L09606, doi:10.1029/2005GL025651, 2006.

Sillmann, J., Kharin, V. V., Zhang, X., Zwiers, F. W., and Bronaugh, D.: Climate extremes indices in the CMIP5 multimodel ensemble: Part 1. Model evaluation in the present climate, J. Geophys. Res.-Atmos., 118, 1716-1733, doi:10.1002/jgrd.50203, 2013.

Simpson, J. J., Berg, J. S., Koblinsky, C. J., Hufford, G. L., and Beckley, B.: The NVAP global water vapor dataset: Independent cross-comparison and multiyear variability, Remote Sens. Environ., 76, 112-129, 2001.

Sitch, S., Smith, B., Prentice, I. C., Arneth, A., Bondeau, A., Cramer, W., Kaplan, J. O., Levis, S., Lucht, W., Sykes, M. T., Thonicke, K., and Venevsky, S.: Evaluation of ecosystem dynamics, plant geography and terrestrial carbon cycling in the LPJ dynamic global vegetation model, Glob. Change Biol., 9, 161-185, doi:10.1046/j.1365-2486.2003.00569.x, 2003. 
Soden, B. J., Jackson, D. L., Ramaswamy, V., Schwarzkopf, M. D., and Huang, X. L.: The radiative signature of upper tropospheric moistening, Science, 310, 841-844, doi:10.1126/science.1115602, 2005.

Sperber, K., and Kim, D.: Simplified metrics for the identification of the Madden-Julian oscillation in models, Atmos. Sci. Lett., 13, 187-193, doi:10.1002/asl.378, 2012.

Stoner, A. M. K., Hayhoe, K., and Wuebbles, D. J.: Assessing General Circulation Model Simulations of Atmospheric Teleconnection Patterns, J. Climate, 22, 4348-4372, doi:10.1175/2009JCLI2577.1, 2009.

Sun, D.-Z., Yu, Y., and Zhang, T.: Tropical Water Vapor and Cloud Feedbacks in Climate Models: A Further Assessment Using Coupled Simulations, J. Climate, 22, 1287-1304, doi:10.1175/2008JCLI2267.1, 2009.

Takahashi, T., Sutherland, S. C., Wanninkhof, R., Sweeney, C., Feely, R. A., Chipman, D. W., Hales, B., Friederich, G., Chavez, F., Sabine, C., Watson, A., Bakker, D. C. E., Schuster, U., Metzl, N., Yoshikawa-Inoue, H., Ishii, M., Midorikawa, T., Nojiri, Y., Körtzinger, A., Steinhoff, T., Hoppema, M., Olafsson, J., Arnarson, T. S., Tilbrook, B., Johannessen, T., Olsen, A., Bellerby, R., Wong, C. S., Delille, B., Bates, N. R., and de Baar, H. J. W.: Climatological mean and decadal change in surface ocean $p \mathrm{CO}_{2}$, and net sea-air $\mathrm{CO}_{2}$ flux over the global oceans, Deep Sea Res. Pt. II, 56, 554-577, doi:10.1016/j.dsr2.2008.12.009, 2009.

Tarnocai, C., Canadell, J. G., Schuur, E. A. G., Kuhry, P., Mazhitova, G., and Zimov, S.: Soil organic carbon pools in the northern circumpolar permafrost region, Global Biogeochem. Cy., 23, GB2023, doi:10.1029/2008GB003327, 2009.

Taylor, K. E.: Summarizing multiple aspects of model performance in a single diagram, J. Geophys. Res., 106, 7183-7192, 2001.

Taylor, K. E., Stouffer, R. J., and Meehl, G. A.: A Summary of the CMIP5 Experiment Design, available at: http://cmip-pcmdi.llnl. gov/cmip5/docs/Taylor_CMIP5_design.pdf (last access: October 2013), 2009 (with updates/corrections made 22 January 2011).

Taylor, K. E., Stouffer, R. J., and Meehl, G. A.: An Overview of CMIP5 and the Experiment Design, Bull. Am. Meteor. Soc., 93, 485-498, doi:10.1175/BAMS-D-11-00094.1, 2012.

Taylor, P. K. (Ed.): Final report of the Joint WCRP/SCOR Working Group on Air-Sea Fluxes: Intercomparison and validation of ocean-atmosphere energy flux fields, WCRP-112, available at: http://eprints.soton.ac.uk/69522/1/wgasf_final_rep.pdf (last access: May 2014), 2000.

Thornton, P. E. and Rosenbloom, N. A.: Ecosystem model spin-up: estimating steady state conditions in a coupled terrestrial carbon and nitrogen cycle model, Ecol. Model., 189, 25-48, 2005.

Tian, B., Fetzer, E. J., Kahn, B. H., Teixeira, J., Manning, E., and Hearty, T.: Evaluating CMIP5 Models using AIRS Tropospheric Air Temperature and Specific Humidity Climatology, J. Geophys. Res.-Atmos., 118, 114-134, doi:10.1029/2012JD018607, 2013.

Todd-Brown, K. E. O., Randerson, J. T., Post, W. M., Hoffman, F. M., Tarnocai, C., Schuur, E. A. G., and Allison, S. D.: Causes of variation in soil carbon simulations from CMIP5 Earth system models and comparison with observations, Biogeosciences, 10, 1717-1736, doi:10.5194/bg-10-1717-2013, 2013.

Trenberth, K. E. and Fasullo, J. T.: Simulation of present-day and twenty-first-century energy budgets of the Southern Oceans, J. Climate, 23, 440-454, doi:10.1175/2009JCLI3152.1, 2010.
Trenberth, K. E., Smith, L., Qian, T., Dai, A., and Fasullo, J.: Estimates of the global water budget and its annual cycle using observational and model data, J. Hydrometeorol., 8, 758-769, doi:10.1175/JHM600.1, 2007.

Vertenstein, M., Craig, T., Middleton, A., Feddema, D., and Fischer, C.: CCSM4.0 User's Guide, available at: http://www.cesm. ucar.edu/models/ccsm4.0/ccsm_doc/ug.pdf (last access: October 2013), 2010.

Vial, J., Dufresne, J.-L., and Bony, S.: On the interpretation of intermodel spread in CMIP5 climate sensitivity estimates, Clim. Dynam., 41, 3339-3362, doi:10.1007/s00382-013-1725-9, 2013.

Waliser, D. E., Blanke, B., Neelin, J. D., and Gautier, C.: Shortwave feedbacks and El Niño-Southern Oscillation: Forced ocean and coupled ocean-atmosphere experiments, J. Geophys. Res., 99, 25109-25125, 1994.

Wang, C. and Picaut, J.: Understanding ENSO Physics - A Review, in: Earth's Climate: The Ocean-Atmosphere Interaction, edited by: Wang, C., Xie, S. P., and Carton, J. A., American Geophysical Union, 21-48, doi:10.1029/147GM02, 2004.

Wang, X. J., Le Borgne, R., Murtugudde, R., Busalacchi, A. J., and Behrenfeld, M.: Spatial and temporal variations in dissolved and particulate organic nitrogen in the equatorial Pacific: biological and physical influences, Biogeosciences, 5, 1705-1721, doi:10.5194/bg-5-1705-2008, 2008.

Wang, X. J., Behrenfeld, M., Le Borgne, R., Murtugudde, R., and Boss, E.: Regulation of phytoplankton carbon to chlorophyll ratio by light, nutrients and temperature in the Equatorial $\mathrm{Pa}-$ cific Ocean: a basin-scale model, Biogeosciences, 6, 391-404, doi:10.5194/bg-6-391-2009, 2009a.

Wang, X. J., Murtugudde, R., and Le Borgne, R.: Nitrogen uptake and regeneration pathways in the equatorial Pacific: a basin scale modeling study, Biogeosciences, 6, 2647-2660, doi:10.5194/bg6-2647-2009, 2009b.

Wang, Y.-M., Lean, J. L., and Sheeley Jr., N. R.: Modeling the sun's magnetic field and irradiance since 1713, Astrophys. J., 625, 522-538, doi:10.1086/429689, 2005.

Washington, W. M., Weatherly, J. W., Meehl, G. A., Semtner Jr., A. J., Bettge, T. W., Craig, A. P., Strand Jr., W. G., Arblaster, J., Wayland, V. B., James, R., and Zhang, Y.: Parallel climate model (PCM) control and transient simulations, Clim. Dynam., 16, 755-774, doi:10.1007/s003820000079, 2000.

Wei, T., Yang, S., Moore, J. C., Shi, P., Cui, X., Duan, Q., Xu, B., Dai, Y., Yuan, W., Wei, X., Yang, Z., Wen, T., Teng, F., Gao, Y., Chou, J., Yan, X., Wei, Z., Guo, Y., Jiang, Y., Gao, X., Wang, K., Zheng, X., Ren, F., Lv, S., Yu, Y., Liu, B., Luo, Y., Li, W., Ji, D., Feng, J., Wu, Q., Cheng, H., He, J., Fu, C., Ye, D., Xu, G., and Dong, W.: Developed and developing world responsibilities for historical climate change and $\mathrm{CO}_{2}$ mitigation, Proc. Natl. Acad. Sci. USA, 109, 12911-12915, doi:10.1073/pnas.1203282109, 2012.

Weickmann, K. M., Lussky, G. R., and Kutzbach, J. E.: Intraseasonal (30-60 Day) fluctuations of Outgoing Longwave Radiation and $250 \mathrm{mb}$ streamfunction during northern winter, Mon. Weather Rev., 113, 941-961, 1985.

Welp, L. R., Keeling, R. F., Meijer, H. A. J., Bollenbacher, A. F., Piper, S. C., Yoshimura, K., Francey, R. J., Allison, C. E., and Wahlen, M.: Interannual variability in the oxygen isotopes of atmospheric $\mathrm{CO}_{2}$ driven by El Niño, Nature, 477, 579-582, 2011. 
Wentz, F. J.: A well-calibrated ocean algorithm for SSM/I, J. Geophys. Res., 102, 8703-8718, 2000.

Wentz, F. J.: SSM/I Version-7 Calibration Report, Remote Sensing Systems, Santa Rosa, CA, available at: http://www.remss.com/papers/tech_reports/2012_Wentz_

011012_Version-7_SSMI_Calibration.pdf (last access: May 2014), 2013.

Wheeler, M. C. and Kiladis, G. N.: Convectively coupled equatorial waves: Analysis of clouds and temperature in the wavenumberfrequency domain, J. Atmos. Sci., 56, 374-399, 1999.

Wilcox, E. M. and Donner, L. J.: The Frequency of Extreme Rain Events in Satellite Rain-Rate Estimates and an Atmospheric General Circulation Model, J. Climate, 20, 53-69, doi:10.1175/JCLI3987.1, 2007.

Wittenberg, A. T.: ENSO response to altered climates, Ph.D. thesis, Princeton University, 475 pp., 2002.

Wittenberg, A. T., Rosati, A., Lau, N.-C., and Ploshay, J. J.: GFDL's CM2 Global Coupled Climate Models. Part III: Tropical Pacific Climate and ENSO, J. Climate, 19, 698-722, doi:10.1175/JCLI3631.1, 2006.

Wu, R. and Kirtman, B. P.: Regimes of seasonal air-sea interaction and implications for performance of forced simulations, Clim. Dynam., 29, 393-410, 2007.

Wu, R. G., Chen, J. P., and Wen, Z. P.: Precipitation-surface temperature relationship in the IPCC CMIP5 Models, Adv. Atmos. Sci., 30, 766-778, doi:10.1007/s00376-012-2130-8, 2013.

Xavier, P. K., Duvel, J.-P., Braconnot, P., and Doblas-Reyes, F. J.: An Evaluation Metric for Intraseasonal Variability and its Application to CMIP3 Twentieth-Century Simulations, J. Climate, 23, 3497-3508, doi:10.1175/2010JCLI3260.1, 2010.

Xie, P. P. and Arkin, P. A.: Global precipitation: A 17-year monthly analysis based on gauge observations, satellite estimates, and numerical model outputs, Bull. Am. Meteor. Soc., 78, 2539-2558, 1997.

$\mathrm{Xu}, \mathrm{R}$. and Prentice, I. C.: Terrestrial nitrogen cycle simulation with a dynamic global vegetation model, Glob. Change Biol., 14, 1745-1764, doi:10.1111/j.1365-2486.2008.01625.x, 2008.

Yang, J., Wang, B., and Wang, B.: Anticorrelated intensity change of the quasi-biweekly and 30-50 day oscillations over the South China Sea, Geophys. Res. Lett., 35, L16702, doi:10.1029/2008GL034449, 2008.
Yuan, H., Dickinson, R. E., Dai, Y., Shaikh, M. J., Zhou, L., and Shangguan, W., Ji, D.: A 3D Canopy Radiative Transfer Model for Global Climate Modeling: Description, Validation, and Application, J. Climate, 27, 1168-1192, doi:10.1175/JCLI-D-1300155.1, 2014.

Zhang, C., Dong, M., Hendon, H. H., Maloney, E. D., Marshall, A., Sperber, K. R., and Wang, W.: Simulations of the MaddenJulian oscillation in four pairs of coupled and uncoupled global models, Clim. Dynam., 27, 573-592, doi:10.1007/s00382-0060148-2, 2006.

Zhang, G. J.: Convective quasi-equilibrium in midlatitude continental environment and its effect on convective parameterization, J. Geophys. Res., 107, ACL 12-1-ACL 12-16, doi:10.1029/2001JD001005, 2002.

Zhang, G. J. and McFarlane, N. A.: Role of convective scale momentum transport in climate simulation, J. Geophys. Res., 100, 1417-1426, 1995.

Zhang, G. J. and Mu, M.: Effects of modifications to the ZhangMcFarlane convection parameterization on the simulation of the tropical precipitation in the National Center for Atmospheric Research Community Climate Model, version 3, J. Geophys. Res., 110, D09109, doi:10.1029/2004JD005617, 2005a.

Zhang, G. J. and Mu, M.: Simulation of the Madden-Julian Oscillation in the NCAR CCM3 Using a Revised Zhang-McFarlane Convection Parameterization Scheme, J. Climate, 18, 40464064, doi:10.1175/JCLI3508.1, 2005b.

Zhang, R.-H. and Levitus, S.: Interannual variability of the coupled Tropical Pacific ocean-atmosphere system associated with the El Niño/Southern Oscillation, J. Climate, 10, 1312-1330, 1997.

Zhang, R.-H. and Busalacchi, A. J.: Rectified effects of tropical instability wave (TIW)-induced atmospheric wind feedback in the tropical Pacific, Geophys. Res. Lett., 35, L05608, doi:10.1029/2007GL033028, 2008.

Zhang, R.-H., Zheng, F., Zhu, J., and Wang, Z.: A successful realtime forecast of the 2010-11 La Niña event, Sci. Rep., 3, 1108, doi:10.1038/srep01108, 2013.

Zhang, Y., Wallace, J. M., and Battisti, D. S.: ENSO-like interdecadal variability: 1900-93, J. Climate, 10, 1004-1020, 1997.

Zhao, M. S., Heinsch, F. A., Nemani, R. R., and Running, S. W.: Improvements of the MODIS terrestrial gross and net primary production global data set, Remote Sens. Environ., 95, 164-176, doi:10.1016/j.rse.2004.12.011, 2005. 